University of Rhode Island

DigitalCommons@URI

Open Access Dissertations

2019

\title{
A Phenomenological Study of Perspectives on Teacher Diversity and the Lived Experiences of Black Public School Teachers
}

Michael Browner Jr.

University of Rhode Island, mbrownerjr@gmail.com

Follow this and additional works at: https://digitalcommons.uri.edu/oa_diss

\section{Recommended Citation}

Browner, Michael Jr., "A Phenomenological Study of Perspectives on Teacher Diversity and the Lived Experiences of Black Public School Teachers" (2019). Open Access Dissertations. Paper 831. https://digitalcommons.uri.edu/oa_diss/831

This Dissertation is brought to you for free and open access by DigitalCommons@URI. It has been accepted for inclusion in Open Access Dissertations by an authorized administrator of DigitalCommons@URI. For more information, please contact digitalcommons@etal.uri.edu. 


\title{
A PHENOMENOLOGICAL STUDY OF PERSPECTIVES ON TEACHER DIVERSITY AND THE LIVED EXPERIENCES OF BLACK PUBLIC SCHOOL TEACHERS
}

\author{
By \\ MICHAEL BROWNER, JR.
}

\begin{abstract}
A DISSERTATION SUBMITTED IN PARTIAL FULFILLMENT OF THE REQUIREMENTS FOR THE DEGREE OF DOCTOR OF PHILOSOPHY

IN

EDUCATION
\end{abstract}

UNIVERSITY OF RHODE ISLAND

AND

RHODE ISLAND COLLEGE

2019 


\title{
DOCTOR OF PHILOSOPHY DISSERTATION
}

OF

MICHAEL BROWNER, JR.

APPROVED:

\section{Dissertation Committee}

\author{
Major Professor \\ Stefan Battle \\ C. David Brell \\ David Byrd \\ Vanessa Quainoo \\ Gerri August \\ Interim Co-Dean, Feinstein School of Education - RIC \\ Julie Horwitz \\ Interim Co-Dean, Feinstein School of Education - RIC \\ Nasser H. Zawia \\ Dean, The Graduate School - URI \\ UNIVERSITY OF RHODE ISLAND \\ AND \\ RHODE ISLAND COLLEGE \\ 2019
}




\begin{abstract}
The purpose of this study was to explore the perspectives and lived experiences of Black public school teachers as related to the underrepresentation of Black teachers in the teaching profession. Data were collected through interviews with ten teachers who identified as Black and were employed by two school districts in northeastern Rhode Island. Through phenomenology as a methodology, and autoethnography as a method, this study sought to explore the lived experiences of Black teachers in contemporary public school settings and their perspectives on teacher diversity. This study provides an in-depth and intimate understanding of what it is like and what it means to be a Black teacher and the various emotionally charged and sensitive topics experienced by members of the group experiencing this phenomenon. This study focuses on what can be learned from the stories that each person brought to the research encounter and how to improve diversity in the teacher workforce.
\end{abstract}

Keywords: autoethnography, Black teachers, professional educators, diversity 


\section{Acknowledgements}

I have always believed that Black men can best serve their families and their communities by expecting and demanding more of themselves. My pursuance of the degree of Doctor of Philosophy in Education further supports this belief.

There are several people to whom I wish to dedicate this dissertation. First and foremost, I dedicate this work to the Browner family and to our legacy of hard work and perseverance which was most consistently exhibited through the life of my late paternal grandfather, Mr. Horace M. Browner (1924-2017). Without the overwhelming love, support, and encouragement of my family, I would not have been able to complete this dissertation. I wish to acknowledge and thank my father, Mr. Michael Browner, Sr., for his faith in my ability to reach my goal because he has always believed in me and has taught me to believe that I am a winner. I further dedicate this work to the memory of my late mother, Ms. Katherine E. Browner (1950-2017), and my late maternal grandmother, Ms. Frances G. Batey (1926-2007); although they did not live to see me complete this work, they both had a strong desire to refer to me as "Dr. Browner!" The steadfast support of my son, Price Alexander, has been unending as we both toiled through the ranks of academia in our quests to attain higher education. The love of my stepmother, Mrs. Kim Veloza-Browner, has blessed me since I was ten years old. Lastly, I acknowledge the collective guidance of my dissertation committee members: Dr. Stefan Battle, Dr. David Brell, Dr. David Byrd, and Dr. Vanessa Quainoo.

It is essential that I acknowledge and further dedicate this work to the memory of Mrs. Pauline Hudson Barge (1924-2006), my first and only Black teacher. Mrs. Barge was the epitome of a strong and charismatic Black woman and she was, without question 
or pause, the consummate educator who exhibited more class and dignity than any teacher I have ever known. Mrs. Barge was born in the Jim Crow south at a time when it was dangerous to even be Black, yet she taught for 38 consecutive years (1956-1994) and changed the lives of countless elementary school children in both her native Selma, Alabama and Newport, Rhode Island. Mrs. Barge earned a master's degree at a time when southern parks, water fountains, movie theaters, and restaurants were clearly marked "Colored" and "White Only." As one of Mrs. Barge's fourth graders I learned long division and the four kinds of sentences (declarative, imperative, interrogative, and exclamatory). And for the first time, I also learned about people who looked like me with such names as Mary McLeod Bethune, Booker T. Washington, Marian Anderson, and Dr. Carter G. Woodson. Most importantly I learned about a special kind of love that often can only be experienced at school: a teacher's love. I thank God for the life and legacy of Mrs. Barge and the impact she has had on my life. 


\section{Table of Content}

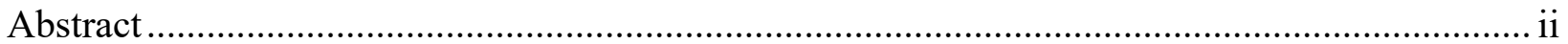

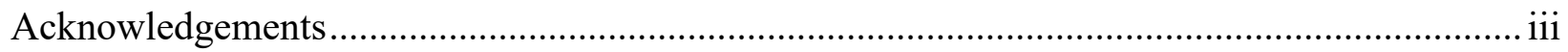

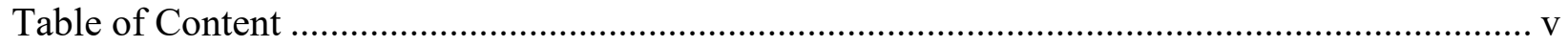

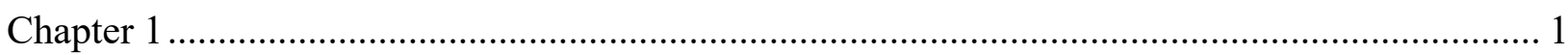

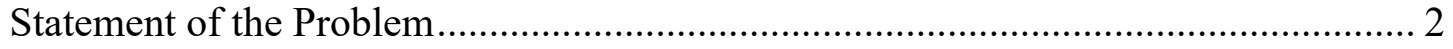

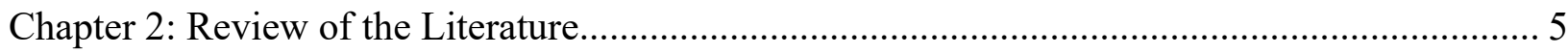

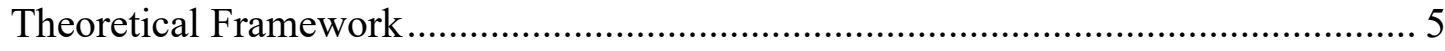

Current Status of Teacher Diversity ............................................................ 8

Teacher Diversity: An Issue of Demographics and Democracy ............................. 13

What Increased Teacher Diversity Can Accomplish ............................................ 15

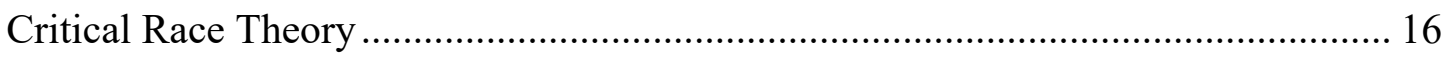

Critical Race Theory as a Theoretical Framework ............................................... 18

Critical Race Theory and Teacher Diversity ................................................... 20

Critical Race Theory and Microaggressions ................................................... 23

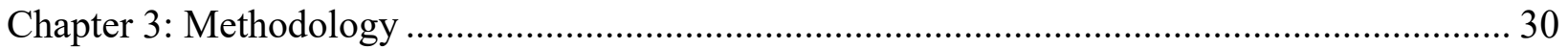

Methodological Framework ..................................................................... 30

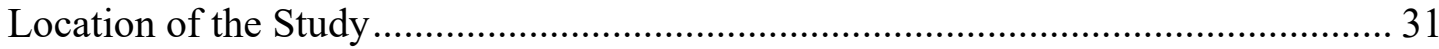

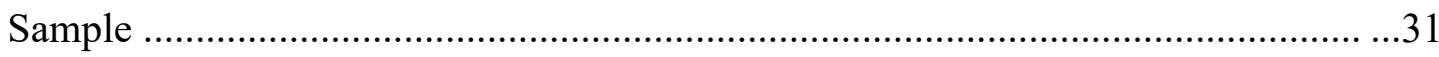

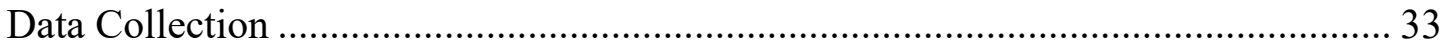

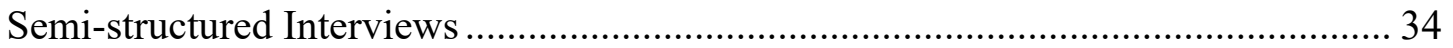

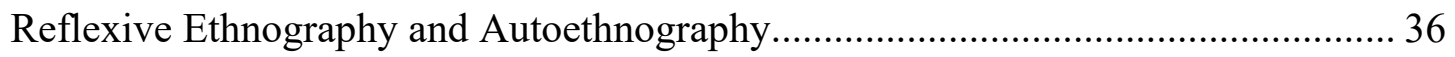

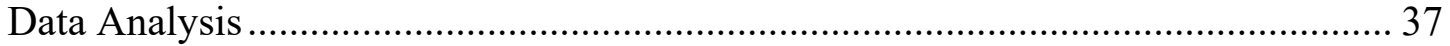




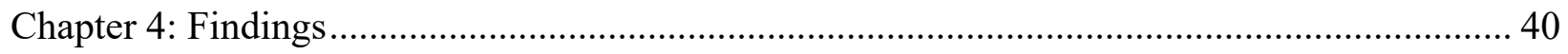

Personal Educational Experience .......................................................................... 40

Professional Experience as a Classroom Teacher......................................................... 45

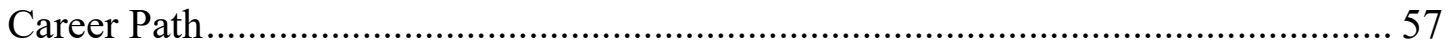

Teacher Diversity and Teacher Recruitment and Retention ....................................... 71

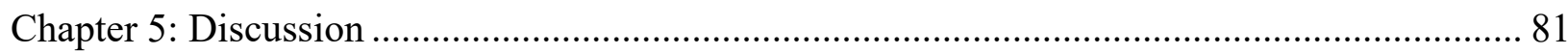

Implications for Future Applications of CRT …………………………………..... 81

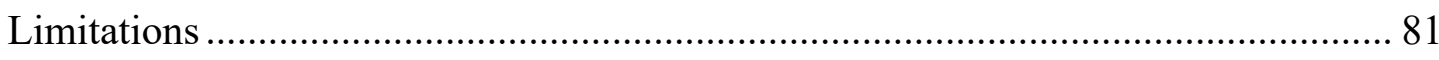

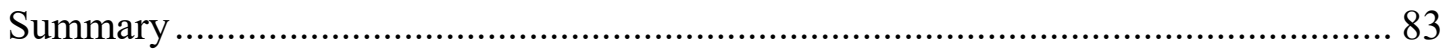

Professional Experience as a Classroom Teacher................................................ 83

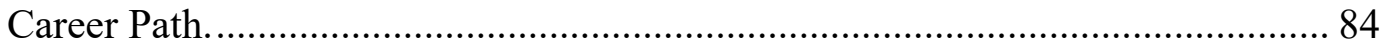

Teacher Diversity and Teacher Recruitment and Retention................................ 85

Recommendations for Further Research............................................................. 88

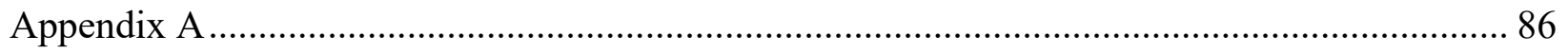

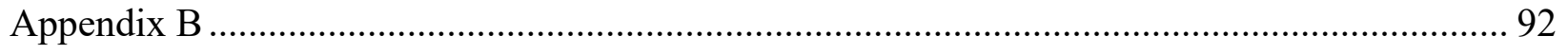

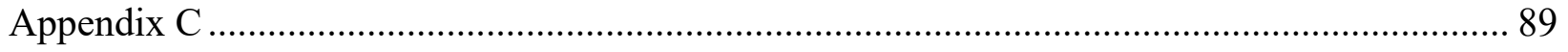

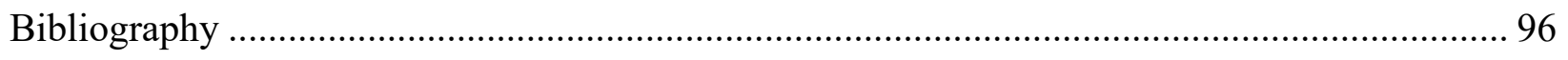




\section{Chapter 1}

There is a growing disparity between the number of teachers of color and students of color in the United States in the nation's public school system. A featured article in The Washington Post stated that: "The challenge persists even as research emerges showing that a Black person's presence at the front of a classroom has the power to dramatically improve a student's trajectory" (Richman, 2018). This statement is true for my primary, secondary, and college/university educational experiences.

American schools today are experiencing a significant student demographic shift, with increasing numbers of students of color. Unfortunately, the teacher workforce does not reflect this diversity, and diversifying the teaching profession is an act of disrupting educational inequities (Goings, Brandehoff, \& Bianco, 2018). Teachers of color have a particularly positive effect on students of color; they have been found to hold higher expectations for students of color and to be both more likely to refer students of color into gifted and talented programs and less likely to refer them for suspension and special education (Ford, 2010; Grissom \& Redding, 2016).

I was born and raised in Newport, Rhode Island where I attended the public schools of the city. On the first day of school in September of 1984, I began the fourth grade. This was a day which will live not in infamy but in renown, because it was the day I met the woman who would become the inspiration for my career in education, Mrs. Pauline Hudson Barge, my fourth grade teacher. Regal was not just the model of the pretty white Buick sedan she drove to school each day, but regal is also the best word to describe the aura of this woman. 
Mrs. Barge began her teaching career in the segregated schools of her native Selma, Alabama, in 1956. Prior to her retirement in 1994, I returned to my elementary school for a visit, and was delighted to find Mrs. Barge in the same classroom, still inspiring children in the same way she had inspired me.

In September of 1998, I began my teaching career as a seventh-grade social studies teacher in a middle school in my hometown. When I was hired, I called Mrs. Barge to assist me in organizing and decorating my first classroom. She was thrilled and delighted by the request to assist me. Like Mrs. Barge, I too, have been dedicated to improving the lives of children and families. Early in my career, it became clear to me that I would eventually become the only Black teacher in my school building. Because of this awareness and imbalance, there was a great responsibility to be strong in the presentation of myself and in my classroom delivery, especially for Black children and their families. I worked diligently and passionately for 20 years to bring a sense of pride and dignity to my classroom through my teaching and my interactions with students, families, and colleagues.

\section{Statement of the Problem}

The lack of teacher diversity in American public schools is a problem because research studies have shown that diversifying the teaching profession improves student performance for all students, especially for students of color in low-performing schools (DeRuy, 2014). Research suggests three reasons for the need for increased teacher diversity: a) Black teachers are valuable role models for all students, especially students of color (Quiocho \& Rios, 2000); b) Black teachers are often cultural brokers for students of color in that they have the ability to bring an understanding of students' cultural 
background and experiences (Villegas \& Irvine, 2010); and c) Black teachers have significant impact on other student outcomes, including attendance, advanced placement (AP) enrollment, gifted and talented referral, and college acceptance and attendance rates (Villegas \& Irvine, 2010).

The purpose of this study was to examine the lived experiences of ten Black teachers. The focus of inquiry will be related to their presence, or lack thereof, in American public school classrooms. Therefore, the research question for the study was, how do Black teachers perceive and interpret their lived experiences in the field of education? By addressing this question, I sought to determine whether or not there is value to increase the number of Black teachers and their contribution to American public schools. Efforts to diversify the teaching force are at risk without clear answers to these questions, especially given the weight that empirically-based evidence currently commands in the decision-making process on how to allocate limited public resources, including education (Villegas, Strom \& Lucas, 2012).

Beyond the facts and figures about the recruitment and retention of Black teachers, this study represents the lived experiences of Black teachers as articulated by them. What better way to discover the value and purpose of increased teacher diversity than to directly examine the professional and socialization experiences of Black teachers? It is likely that the most valid and reliable insights on the value and purpose of increased teacher diversity can be directly drawn from Black teachers' articulations of their own lived experiences. The lived experiences and perceptions of Black teachers can also help to add a more informed justification and implementation for greater teacher diversity in America's public schools. 
To meet this aim, I first describe how the scholarly literature addresses such key issues as the current status of teacher diversity, an issue of demographics and democracy, what increased teacher diversity can accomplish, critical race theory in teacher diversity, and critical race theory and microaggressions. I then describe how I used the qualitative methods phenomenologically; these methods consisted of semi-structured interviews and reflexive ethnography/autoethnography to collect and interpret the data addressing participants' reactions to their lived experiences as Black teachers as well as the lack of representation of their racial group in schools. I thematically analyzed the data by looking for themes and patterns relevant to the participant's lived experiences as Black teachers. I also examined the commonality of participants thoughts and feelings about the lack of relative absence of teachers of color, especially Black teachers. Finally, I present these results and discuss their implications.

An important point to make in order to help provide clarity in the presentation of this study is the use of the terms 'Black' and 'African-American' interchangeably at times; as I use them here, both refer to people of African descent who were born in the United States. "Black" does not mean this from a Pan-African, global perspective. Africans consider themselves and are referred to as "Blacks." Additionally, the terms 'minority,' 'teachers of color,' 'students of color,' and 'people of color' each refer to individuals who are non-White.

The terms are appropriately used to articulate and illustrate the study participants and/or scholarly work offered in the study. 


\section{Chapter 2: Review of the Literature}

\section{Theoretical Framework}

For the past several decades, there has been a shortage of teachers of color, and this has been a large issue for, and in, the nation's schools. There is widespread agreement that the American elementary and secondary teaching force should "look like America" (Ingersoll \& May, 2016). It has been expressed that, as the nation's general and student populations have become more racially and ethnically diverse, the teaching force has grown less diverse. As a result, students of color in America's schools are increasingly lacking in adult role models who look like them as well as in having the opportunity for consistent contact with teachers who better understand their racial and cultural backgrounds. The shortage of teachers of color is one of the major reasons that there is an achievement gap between White students and students of color, as well as unequal occupational and life outcomes. It is not an overstatement to say that this shortage is a major civil rights issue (Ingersoll \& May, 2016).

According to Ingersoll and May (2016), the main source of this teaching shortage lies in problems with the teacher supply pipeline. There are too few students of color who enter and complete college and those who do have an increasing number of career and employment options outside of the teaching field. Moreover, when minority candidates decide to enter teaching, they often encounter such barriers as teaching entry exams, on which candidates of color often attain lower scores and lower rates of passing. Such barriers are often caused by limited life experiences and limited exposure, which can be attributed to the shortage of teachers of color. In many instances, entry exams for prospective teachers are not designed for Black or Multicultural candidates. For 
example, as a child I lived in a house that had a detached garage in the backyard. Many of my Black friends and classmates lived in low-income housing where there were no garages (or backyards). By the time a prospective Black teacher candidate takes an entry exam, they may not be aware of such things as a garage; the point is, many Black and Multicultural candidates grow up with disparities through limited life experiences and exposure, which often creates barriers to success.

From a policy perspective, the response to this teacher shortage has been to try to recruit more candidates of color into teaching. In recent decades, there have been numerous government and nongovernment organizations that have tried a variety of teacher recruitment programs and initiatives. These have included future-educator programs in high schools (often referred to as grow-your-own programs), partnerships between community colleges and four-year teacher education programs, career ladders for paraprofessionals in schools, and alternative teaching certification programs. Many of these initiatives have been designed to bring teachers of color (specifically males, who are in the shortest supply) into schools that are predominantly populated by students of color in low-income, urban school districts. One problem with such efforts is that lowincome urban districts are not the only places in which teachers of color are needed. A diverse teaching staff across districts with diverse populations and socioeconomic status is beneficial to all students, including White students who should be afforded the opportunity to recognize that not every qualified teacher or well-educated professional is White.

In a study conducted by Ingersoll and May (2016), in order to uncover minority teacher recruitment, employment, and retention from 1987 to 2013, there was one key 
factor identified for the high concentration of teachers of color who are overwhelmingly employed in low-income, urban districts with high numbers of students of color. That finding is that teachers of color are two to three times more likely than White teachers to work in such conditions identified as, "hard-to-staff schools" (Ingersoll \& May, 2016, p. 3). The data from this study showed that, "in spite of competition from other occupations for minority college graduates, and in spite of apparent barriers to entry, efforts over recent decades to recruit more minority teachers and place them in schools serving disadvantaged and minority student populations appear to have been successful" (Ingersoll \& May, 2016, p. 3). However, on the retention end of this issue, while the subject of demographic characteristics of schools appeared to be important to teachers of color in their initial employment decisions, according to the data what matters more is, when teachers of color decide whether to stay or leave, are school working conditions. Ingersoll and May (2016) asserted that the very same "hard-to-staff" schools that are more likely to hire teachers of color are also more likely to have less desirable working conditions (p. 3). The data suggest that this finding accounts for the higher rates of minority-teacher turnover (2016). In short, the data indicate that teachers of color are employed at higher rates in schools serving disadvantaged students, but they also depart at higher rates because these same schools tend to be less desirable as workplaces (Ingersoll \& May, 2016).

An even more striking finding from Ingersoll and May (2016) is that the conditions for minority teachers' departures were not lower salary levels, the absence of useful professional development, or the shortage of classroom resources. These all had little association with the departure rate. It was rather the low level of collective faculty 
decision-making influence in the school and the degree to which individual instructional autonomy of teachers. Ingersoll and May (2016) referred to influence and autonomy in the workplace as "key hallmarks of respected professions" and summarized their data with the assertion that "schools that provided more teacher discretion and autonomy, as well as schools with higher levels of faculty input into school decision making, had significantly lower levels of minority teacher turnover" (p. 5).

The growing mismatch between the degree of racial/ethnic diversity in the nation's student population and the degree of diversity in the nation's elementary and secondary teaching workforce (Quiocho \& Rios, 2000; Villegas, Strom \& Lucas, 2012) is the topic of many previous research studies. Since there is limited empirical research on the perspectives of Black teachers themselves and their thoughts on teacher diversity, the main focus of this literature review is to examine three topics. First, the current status of teacher diversity; second, teacher diversity as an issue of demographics and democracy; and third, what increased teacher diversity can accomplish for students, for school districts, and for education in general.

\section{Current Status of Teacher Diversity}

Close to half of the public school students in the United States are students of color (National Center for Education Statistics [NCES], 2015). Yet teachers of color (those who identify as Latino/a, African American, African, Asian American, Pacific Islander, American Indian, and/or biracial) only account for about $15 \%$ of the teaching force (NCES, 2012). An examination of the data clearly shows that education in the United States has a shortage in regard to teachers of color and that students today are significantly more racially diverse than their educators (Boser, 2011). Indeed, these 
statistics show a monumental gap between teacher and student demographics in the United States. Students of color are predicted to make up 55\% of the public school population by 2024 (Kena et al., 2015), but the teacher workforce does not reflect this diversity. For example, during the 2011-2012 school year, $80 \%$ of teachers were White, whereas $51 \%$ of students were non-White. Black and Hispanic students made up 16\% and $24 \%$ of the student population respectively, but Black and Hispanic teachers only accounted for $7 \%$ and $8 \%$ of the teaching workforce (U.S. Department of Education, 2016). The reports declared that to accomplish teacher diversity, greater resources would be needed, barriers examined, and policies put in place to support this goal.

As a 20-year veteran Black teacher, I have personally experienced the impact of the statistics presented in these reports. Upon conducting this study, I had to ask myself more deeply than I had in the past: Why is diversifying the teaching workforce is so important? My research-based answer? Diversifying the teaching profession is an act of disrupting inequities in education and society at the local, state, and national levels. According to current research, and from my own lived experiences, teachers of color can have a particularly positive effect on students of color; we have been found to hold higher expectations for students of color, in the form of both student behavior and academic achievement. Diversifying the teaching workforce is not only a benefit to students of color as teachers of color; teachers of color can equally benefit White students. According to Goings, Brandehoff, and Bianco (2018);

Given the deficit stereotypes placed on men and women of color, being taught by a teacher of color can provide White students with positive images of different racial groups, which is crucial if it is our collective desire as a country to disrupt 
inequities in education and society at large. Yet under the current teacher-staffing paradigm, many White students could go their entire educational career without being taught by a single teacher of color (p. 51).

More recently, The Education Trust (2016) published a report entitled Through Our Eyes: Perspectives and Reflections from Black Teachers, which chronicled the lived experiences of Black teachers and included a sample of 150 teachers in public and public charter schools in seven states. In March of 2015, the research team that was established to conduct this study set out to hear from teachers of color by hosting a series of focus groups with Black and Latino teachers across the country. The team used data from the Schools and Staffing Survey (SASS) (2012) to target states and districts with high numbers of teachers of color, and recruited participants through schools, districts, and teacher organizations. Their goal was to better understand the unique experiences of these teachers, why they teach, their perspectives on the state of education, what they believe they bring to the classroom and to the field, and the challenges they may experience in the workplace because of their race. These findings were presented in November of 2016 and were solely from the focus groups with Black teachers.

The Black teachers whose voices were heard in the aforementioned study were frustrated but remained in the profession because they loved their students and their work, and wanted to be able to fully contribute to the educational success of their students. Many Black teachers, though passionate about their work and the high expectations they have of their students, expressed the limitation of acting as disciplinarians instead of being respected for their ability to manage academic delivery within their classrooms. They also expressed the perception that, though they may relate 
well to students, they had to "tone down" their personalities to be seen as professionals (Griffin \& Tackie, 2016, p. 1). Moreover, many among the participants felt that, "without the acknowledgement of the pedagogical and subject matter expertise essential to their profession, they felt they lacked opportunities for advancement and were undervalued and unappreciated" (Griffin \& Tackie, 2016, p. 1). The researchers noted that they heard similar sentiments everywhere they went, which demonstrates the ubiquitous nature of these issues regardless of context or geography.

The researchers further reported that, "to be clear, our findings are not entirely new; what is new is qualitative findings on Black teachers that are representative of the nation" (Griffin \& Tackie, 2016, p. 2). The researchers explained that, over many years, both qualitative and quantitative research has examined the impact of teachers of color in classrooms and schools. While national data expose retention and hiring trends, qualitative data are necessary to expand and understand attrition among Black teachers. The researchers further ascertain that prior to their study, and by methodological tradition, qualitative studies have focused on small pockets of teachers often within a given state or even a specific district. The qualitative data in the study were expanded to gain an understanding of teachers across the nation and to present findings that can be extended to an entire population of Black teachers and useful to multiple stakeholder groups in education.

New evidence on the importance of diversifying the teaching profession continues to emerge. In April of 2017, Ashley Griffin, then interim director of K-12 research at The Education Trust and co-author of the aforementioned report, Through Our Eyes, reported the publication of a study conducted by the Institute of Labor Economics. 
Griffin (2017) noted that low-income Black students who have a Black teacher for at least one year in elementary school are more likely to complete high school and to consider college. In an article titled The Black Teacher Effect, Griffin said that much of what the Institute of Labor Economics reported is similar to what she heard from Black teachers as she traveled the country talking to them (Griffin, 2017). The experiences of Black teachers, as former or ongoing students themselves, were enriched by having a teacher who looked like them; as educators they provided the kind of relationships, classroom environments, and expectations for students of color that helped them shine. The main question her report examined was, Why do these benefits accrue? Griffin stated "Honestly, we don't know why" (Griffin, 2017). While the answer may not be completely clear, what is clear are the five points heard during the focus groups:

1. Black teachers believe they impact the lives of Black students in ways that differ from their White colleagues.

2. Black teachers develop an initial trust and rapport with Black students that help build relationships that promote learning; teachers expressed the feeling that because of perceived cultural and experiential similarities, students came to trust them more and feel safe in their classrooms, thus creating a conducive learning environment.

3. As role models for Black children, Black teachers feel they are examples of how to overcome challenges in order to become successful in life. Many Black teachers shared their understanding of the lived experiences of their Black students, and, because of this, they feel confident teaching students about challenges of discrimination and, at times, poverty, and 
were well-positioned to help students understand what it takes to be successful in this world.

4. When Black students encounter challenges in the classroom, Black teachers sympathize as White teachers do. The difference is that they do not use these challenges to make excuses for students; but rather to show students these are reasons to press on and succeed.

5. Black teachers often feel an obligation (that they say is somewhat intensified by their limited representation in the teaching workforce) to go beyond teaching solely academics and to educate the entire child, including character-building and everyday life skills. This sense of obligation often comes about because they believe that Black students will not receive high expectations and life skills from White teachers (Griffin, 2017).

In conclusion, Griffin explained that, "in the end, the 'why' doesn't matter as much as the understanding and acknowledgement that students (all students and especially students of color) benefit from learning in a school building staffed with diverse adults" (2017, p. 2). Such benefits can only happen if and when school and district leaders make diversity a priority and make it their intent to recruit and retain teachers of color in the belief that the effects of such a prioritized intent can be lifechanging for all involved.

\section{Teacher Diversity: An Issue of Demographics and Democracy}

The national issue of teacher diversity is both an issue of demographics and of democratic ideals. It is clear that the proportion of students of color in most public 
schools is significantly larger than the number of teachers of color. However, in a democratic society, I believe teacher diversity is an educational civil right for all students. In September of 2015, the Albert Shanker Institute (ASI), endowed by the American Federation of Teachers, issued a status report entitled The State of Teacher Diversity. This report stated that, while there is reason to believe that students of color would likely be the greatest beneficiaries of a diverse teaching force, there is evidence that all students, and national democracy at large, would benefit from a teaching force that reflects the full diversity of the United States population. Of the many research-based points made in the ASI report, there are two in particular that speak to the democratic values that are at the core of reasons for and benefits of greater teacher diversity:

1) positive exposure to individuals from a variety of races and ethnic groups, especially in childhood, can help to reduce stereotypes, attenuate unconscious implicit biases, and help promote cross-cultural social bonding, and

2) all students benefit from being educated by teachers from a variety of different backgrounds, races, and ethnic groups, as this experience better prepares them to succeed in an increasingly diverse society (ASI, 2015, p. 1).

A final point made by the ASI, relative to teacher diversity on a national level and from the collective voices of teachers of color themselves, is that teachers of color are not evenly distributed across schools and tend to be concentrated in urban schools with increased barriers of high-poverty and low socioeconomic status. The ASI further noted that, "survey data show teachers of color are not leaving the profession at a higher rate because of such barriers but because of the working conditions in their schools. The 
strongest complaints of teachers of color are of the lack of collective voice in educational decisions and a lack of professional autonomy in the classroom" (ASI, 2015, p. 2).

\section{What Increased Teacher Diversity Can Accomplish}

A diverse teaching force can assist in bridging the gap between races in terms of academic achievement and providing a greater opportunity for students of color to be educated by teachers who look like them (Quiocho \& Rios, 2000; Villegas \& Irvine, 2010). Villegas and Irvine (2010) further emphasize two additional reasons for teacher diversity: a) teachers of color can serve as positive role models particularly for students of color who may have few who look like them, and b) teachers of color can bring increased stability to hard-to-staff schools. Additionally, teachers of color could offer shared life experiences with students of color that could support their social, emotional, and academic growth (Gay, 2000). This statement resonates with Villegas and Irvine's (2010) discussion of teachers of color as role modeling relationships with students of color. Of all the points of view offered from the majority of cited works, the importance of teachers of color as role models is a recurring theme but one that is lacking in qualitative empirical evidence. As programs are launched to address the disparities between teacher and student diversity, additional research is needed so that recruitment efforts are not rendered vulnerable in the face of limited public funding for education (Villegas \& Irvine, 2010).

From the literature, it seems that teacher race and ethnicity make a difference in the education of all students. The ability to consistently recruit and retain Black teachers requires local, state, and national leaders of education to understand the unique perspectives and experiences of Black teachers themselves, and who better to learn from 
than the teachers themselves? Therefore, the research question for this current study is, how do Black teachers perceive and interpret their lived experiences in the field of education?

\section{Critical Race Theory}

Critical Race Theory (CRT) is focused on the application of an examination of United States society and culture and its connection to the intersection of race, law, and power. The purpose for employing CRT in this study was to examine the ways in which race and racism play a role in the makeup of teaching faculty in American public schools, and the extent to which race makes a difference. It is important to make a connection between CRT and phenomenology, my chosen research methodology; and how CRT holds race as a social phenomenon. Delgado and Stefancic (2012) stated, "Unlike some academic disciplines, critical race theory contains an activist dimension. It tries not only to understand our social situation but to change it; it sets out not only to ascertain how society organizes itself along racial lines and hierarchies but to transform it for the better" (p. 7).

One of the primary tenets of CRT is that race is ordinary, normal, and often a common everyday experience of many people of color in this country. In presenting CRT as the theoretical framework for this study. I use the terms Black and AfricanAmerican interchangeably at times. Additionally, the terms: teachers of color, students of color, and people of color, each refer to individuals who are non-White. It is import and necessary to explain the choice of nomenclature for this study. As a scholar of the lived experiences of Black teachers, it is important to acknowledge this naming process 
and that the term 'Black' was selected in full awareness of its historical and evolutionary implications.

The American historical context has imposed several identities upon Black people. The Trans-Atlantic slave voyage symbolically and actually displaced Africans. But, to think that Africans were a monolithic group is a misnomer. A single slave ship carried many slaves from many different nations, all from the continent of Africa. Africans understood themselves to be of geographic and cultural nationality. So, the person from Nigerian was/is Nigerian, the person from Ghana was/is a Ghanaian, and so forth. This means that Africans who were forcibly brought to America did not have a slave consciousness nor did they identify as inferior. White slave owners created names for African slaves to nullify the African pride and break the African spirit and replace African heritage with slave culture. While this process traumatized our ancestors, it certainly was not holistically successful. While many individuals suffered under the oppression of slavery, we as a people survived.

Consequently, what developed over time was an evolution of Black American identity. The naming progressed from the most derogatory to variations of selfexpression: the 'N' word, Colored, Negro, Black, Afro-American, and African-American are the major terms used. Racial labels have been of specific importance to Black Americans, mainly as a result of the historical loss of their core personal identities during slavery and the period of the Jim Crow laws (Smith, 1992). Subsequently, we should not be surprised that as a people we share ancestral roots but choose to self-express in a variety of geographical and cultural-based identities. Pointing back to our complex beginnings and our forced sojourn in this country, we are not a monolithic people. It is 
important to be aware of this complexity and how the Black "lived experience" is informed by the richness of our historical identity.

\section{Critical Race Theory as a Theoretical Framework}

One of the first questions I raised about CRT in my quest to learn of its origin and emergence as a framework was, what makes race theory (CRT) critical? In an online literary segment on social theory (specifically critical race and postcolonial theory) entitled New Connections to Classical and Contemporary Perspectives, the Routledge Publishing Company provided a very clear and concise answer: "What makes critical race theory 'critical' is that its major aim is to uncover and critique racially oppressive social structures, meanings, and ideas for the purposes of combating racism. As such the two major objects of study and thought for critical theorists of race are, unsurprisingly, race and racism" (Routledge, 2016). The text continued to explain with the assertion that, with regard to race, critical race theorists have presented a major challenge to theories that understand and present race as something "essential" or biologically ingrained in humans. For scholars of CRT, such racial categories as Black, White, Latino, Asian, Native American, and so forth, are social constructions that are not produced biologically. Rather, they are produced by social relationships, cultural meanings, and the institutions of law, politics, religion, and education. Finally, race as a construct has been argued by critical race theorists as a central aspect of modern social organization and in such modern forms of knowledge as human biology, medicine, and law (Routledge, 2016). Increasingly, it has been applied to education.

CRT is a framework that emerged out of the critical legal studies (CLS) movement during the 1970s and was applied to the field of education in the mid to late 
1990s. CLS is a leftist legal movement that challenged the traditional legal scholarship that focused on doctrinal and policy analysis in favor of a form of law that spoke to the specificity of individuals and groups in social and cultural contexts (Gordon, 1990). According to major theorist of CLS and later CRT, Kimberle Crenshaw, "The civil rights struggle represents a long, steady march toward social transformation" (Crenshaw, 1988, p. 1334). Crenshaw further stated, (1988), "Critical [legal] scholars have attempted to analyze legal ideology and discourse as a social artifact which operates to recreate and legitimate American Society" (p. 1350). Scholars in the CLS movement decipher legal doctrine to expose both its internal and external inconsistencies and reveal the ways that "legal ideology has helped create support, and legitimate America's present class structure" (Crenshaw, p. 1350). Finally, the contribution of CLS to legal discourse is in its analysis of legitimating structures in society. According to Ladson-Billings (Taylor, Gillborn, \& Ladson-Billings, 2016), “CLS scholars critique mainstream legal ideology for its portrayal of U.S. society as a meritocracy but failed to include racism in its critique. Thus, CRT became a logical outgrowth of the discontent of legal scholars of color" (p. 18).

The application of CRT to education was made in order to describe how schools, as institutions, functioned to affirm the racial status quo and has since expanded to include empirical research that examines racism within schools (Kohli, 2016). Since the 1990s, CRT has undergone numerous changes in educational studies and has on occasion been prominent in the news. With a focus on racial inequity, however, CRT is regularly accused of being an ideology intended to stir up racial animosity (Taylor, Gillborn, \& Ladson-Billings, 2016). In its current regard of being a controversial approach, one of 
CRT's core principles is that racism is so common as to be regarded as a normal (and, therefore, as an acceptable, inevitable, and unchallenged) feature of contemporary life, an aspect of the everyday realities experienced by people of color. To that end, and despite opposition by some White political detractors, CRT has grown to become a well-known and popular approach to understanding and opposing racism in education (Taylor, Gillborn, \& Ladson-Billings, 2016).

\section{Critical Race Theory and Teacher Diversity}

To better understand CRT as it relates to teacher diversity and the lived experiences of Black teachers, it is necessary to first examine the subject from three viewpoints. First, occupational barriers for communities of color; second, the legal system of segregated schools; and third, trends within the teaching profession.

Occupational barriers for communities of color have existed for many years but have changed throughout history (Ahmad \& Boser, 2014). For example, during the late nineteenth and early twentieth centuries in the southern United States, segregated public schools for African Americans were frequently and completely staffed with African American teachers. In many areas of the country beyond the South, this practice continued until midway through the twentieth century. It was not until the 1954 Supreme Court decision in the case of Brown v. Board of Education, which declared de jure segregated public schools unconstitutional, that integration became the law of the land and was slowly and unevenly implemented and then only to a point. This legislation forced many formerly all-Black schools to close, and Black students were bussed to White schools. As a result, many Black teachers lost their jobs to White teachers, and in the following decades they were pushed further out of the profession altogether through 
firings, demotions, and forced resignations. By 1970, more than 38,000 African

American teachers had lost their jobs (Ahmad \& Boser, 2014). From the 1970s on, more professional opportunities for African Americans (women in particular) opened up outside of education, creating a wider selection of occupations for them to choose from.

One result of these trends was that teaching became a predominantly White (and female-dominated) profession. The Center for American Progress (CAP) further detailed the current trends in numbers, with $82 \%$ of public school teachers identifying as White, while the nation's students have become increasingly diverse (2014). In 2011, 52\% of the 50 million students enrolled in public elementary and secondary schools were White, and today students of color make up nearly half of the nation's public schools' population. In two of the country's most populous states, California and Texas, there already exists a majority of students of color. In fact, CAP estimates that by the year 2043, people of color will make up more than half of the American population, which means that they are extremely likely to represent more than half of the students in public schools (Ahmad \& Boser, 2014).

According to Gloria Ladson-Billings (1998), CRT's usefulness in understanding educational inequity requires a critique of some of the civil rights era's most cherished legal victories and educational reform movements, such as multiculturalism. Sixty-three years after the Brown v. Board of Education decision, many students of color still attend schools that are in reality segregated and unequal (Kozol, 1991; 2005). One aspect of that inequity is the disproportionately low numbers of teachers of color in America's public schools. To gain an understanding of why such low numbers of teachers of color exist, it is essential to offer a historical perspective. In 1954, when the landmark Brown 
v. Board of Education case was argued, won, and then made the clarion call for an end to de jure segregation in America's public schools, Black children left the dilapidated schools in their segregated communities for modern and better equipped, historicallyWhite schools. Inevitably, racial intolerance remained intact, and White families did not send their children to the historically Black schools at the same rate. A consequence of this was that many Black teachers were forced out of the profession, and within ten years, by 1964 , over $45 \%$ of Black teachers were fired (Kohli, 2016). The loss of this population of educators seems not to have recovered and has only grown more disproportionate, hence the purpose of the study.

It is also essential to offer an additional perspective on where the growing inequity of teachers of color originated. Cheryl Harris (1993) argued that our nation and its laws were constructed to protect White property rights, including both the seizure of Indigenous land and the appropriation of the bodies and labor of enslaved people. As a result, an inherent protection of material assets associated with whiteness is embedded in current American institutions and laws. Ladson-Billings and Tate (1995) applied Harris's framework to understanding racial disparities in education by building on the argument that the United States is built on property rights over human rights. They further argued that schools are designed to serve White economic interests through disparate educational opportunities (Ladson-Billings \& Tate, 1995).

Looking through Harris's lens of whiteness as property, it is important to recognize that public schools historically, and currently, are not structured to serve communities of color. From the days of de jure segregation to the continued current existence of de facto segregation, inequalities in such educational realms as school 
funding have consistently pushed students of color into overcrowded and under-resourced schools when compared with their White counterparts. From the threat of physical violence, and even death during the days of integration, to heightened rates of suspension and expulsion, many students of color receive the consistent message that they do not belong in American schools (Kohli, 2016). Even in instances in which communities of color have created and executed organized resistance to these injustices, the fact that such injustices are so deeply embedded in institutional racism prevents systemic change.

\section{Critical Race Theory and Microaggressions}

The concept of microaggressions has been utilized in academic research since the late 1960s (Pierce, 1969). The term "microaggressions" was first introduced by Dr. Chester Pierce, an African American psychiatrist and scholar, in 1970. Pierce (1988) argued that, "all Blacks must have a firm theoretical grasp of racism in order to dilute its crippling effect" (p. 33). In effect, Pierce has meticulously theorized the concept of racial microaggressions for over 40 years to understand how African Americans experience this form of everyday racism. According to Huber and Solorzano (2014), "microaggressions are a form of systemic, everyday racism used to keep those at the racial margins in their place" (p. 1).

Scholars of CRT have borrowed the term microaggressions to discuss the covert forms of systemic racism that exist in society, including educational institutions (Kohli, 2016). CRT scholars have defined racial microaggressions in three ways. First, as subtle verbal and non-verbal insults/assaults directed toward people of color, often carried out automatically or unconsciously. Second, they are described as layered insults/assaults based on one's race, gender, class, sexuality, language, immigration status, phenotype, 
accent, or name. Thirdly, they are categorized as cumulative insults/assaults that take their toll on people of color (Kohli, 2016). In isolation, racial microaggressions may not have much meaning or impact; however, as repeated slights, the effects can be profound (Kohli \& Solorzano, 2012). Because of their elusiveness, it can be hard to pinpoint racial microaggressions as racism, even though they have very real manifestations and consequences for people of color, and in the case of this study, Black teachers.

For the purposes of this study, it is necessary to clarify the connections between CRT and lived experiences. One theorist who offers such a connection is Paulo Freire, who presented the roots of his lived experiences as an empowering educator in his book Pedagogy of the Oppressed (1993). Freire's experience as a child of a middle-class family that had lost its economic base enabled him to identify and develop solidarity with children who had similar experiences, which led to Freire's rejection of a class-based society. Freire (1993) offered a detailed class analysis in which he consistently argued that a thorough understanding of oppression must always go through some form of class analysis. As a component of CRT, microaggressions are a form of oppression that create a struggle between the oppressor and the oppressed. Freire (1993) spoke to this struggle with his assertion that "the behavior of the oppressed is a prescribed behavior, following as it does the guidelines of the oppressor" (p. 47). Microaggressions, conscious yet unintentional, are cumulative and are interpretive-based on the relationship between the oppressed and the oppressor. Moreover, Freire assessed oppression in a way that is hopeful of a transformation toward improved humanity, noting, "To surmount the situation of oppression, people must first critically recognize its causes, so that through transforming action they can create a new situation, one which makes possible the pursuit 
of a fuller humanity" (1993, p. 47). After learning the six steps of his pedagogy that Freire (1993) outlined, I was able to make a strong connection between steps one (submergence - the oppressed person is submerged), four (objectification - do not let the situation define you; no longer submerged), and five (emergence - plans of action must be devised by the oppressed) which has enabled me to learn how to deal with microaggressions throughout my life and career, and how to emerge from them.

Therefore, it is necessary to explain what CRT offers that other, less critical theories do not, and to provide more explicitness about what it means to be critical. As previously mentioned, what makes CRT critical is that its major aim is to uncover and critique racially oppressive social structures, meanings, and ideas for the purpose of combating racism. CRT is not limited to the cultural interpretation of race and the racism of human interaction; it considers the historical, economic, and political structures that have had a critical impact on race and racism, employing an activist dimension that tries not only to understand a social situation but to change it. CRT sets out not only to ascertain how society organizes itself along racial lines and hierarchies but to transform it for the better.

I believe that CRT can provide insight to critical racial concerns in the United States in such circumstances as racial profiling and various other microaggressions that are part of the daily life experiences of people of color. As a Black American man, the only teacher of color in my urban public school, and the only Black male candidate in a state university doctoral program, I constantly experience race at the forefront of my life and as a consistent aspect of my daily experience. In the beginning of part I of Racial Formation in the United States, Omi and Winant (2015) refer to the ways in which racial 
identity is conceptualized in terms of attitudes and beliefs, religion, language, "lifestyle," and group identification (p. 22). This reference reminds me of various life experiences with race from my childhood to the present. My earliest memory of the recognition and perhaps the acknowledgement of my color was as a child reading Ezra Jack Keats's now classic book, The Snowy Day, in which a little Black boy named Peter stays home from school to enjoy the outdoor elements of a snowy day. Keats's book was the first time I had ever observed a Black child depicted in a book. Many years later my elementary school librarian, who had first introduced The Snowy Day to me and my classmates, became a colleague of mine. Having heard me speak of the strong impact that Keats's book had on me, this dear woman (who is White) gave me a brand new copy of The Snowy Day following her retirement celebration.

I am further reminded of a more recent experience when I purchased my first brand new car in September of 2015. I vividly recall telling myself that it would be in my best interest to go to the dealership in formal clothing to receive better treatment and subsequently a better deal. I bought the car on a Sunday after church when I was already dressed in a suit and tie, and I received both royal treatment and a very fair deal. The likelihood of the same experience on a Saturday while dressed in blue jeans and a baseball cap seemed slim, based on other, similar life experiences. In trying to understand Omi and Winant's explanation and interpretation of ethnicity theory and the racist element of the aforementioned experience, I cannot help but think that a White person has far less reason to plan how they will dress or present themselves when buying a car, but a Black person must plan accordingly because Black folk still dwell in a society and among individuals who say, in reference to Black folk, "They all look alike" (2015, 
p. 44). Even in 2018, CRT informs us that Black folk must think and act differently to get results equal to those of Whites.

It is important to analyze the forms of racism that create injustices in schools for both students and teachers of color. According to Huber and Solorzano (2014), institutional racism is a key component to understanding the function and permanence of racism in the United States. Additionally, systemic "racism is embedded within social institutions" such as schools, which in turn serve as "structural mechanisms that perpetuate racism" (Huber \& Solorzano, 2014). Unless there is a structural understanding of the racism that exists in the daily lives of people of color, it will remain a continually difficult phenomenon to change. When institutional racism is understood as a mechanism that guides policies, practices, and processes in education strategically, then and only then can there begin to emerge an understanding of the significance of institutional racism in the lives of all (Huber \& Solorzano, 2014).

When and how will this emergence occur and what will it take to expose and foster such social awareness? One proposed answer is that when school leaders from the federal, state, and local levels actively oppose institutional norms and practices of "whiteness as property", schools can begin the process of systemic change. Until that happens, many public schools will continue to function as hostile racial climates for both students and teachers of color.

It is important again to point out how CRT differs from other theoretical approaches that hold race as a social phenomenon. To quote from Delgado and Stefancic's (2012) aptly titled book Critical Race Theory, "Unlike some academic disciplines, critical race theory contains an activist dimension. It tries not only to 
understand our social situation but to change it; it sets out not only to ascertain how society organizes itself along racial lines and hierarchies but to transform it for the better" (p. 7). This activist dimension is what characterizes contemporary "critical" theories.

There are two particular theoretical approaches that come to mind which also hold race as a social phenomenon: stratification theory and postcolonial theory. Stratification theory is a theoretical approach which deals with the social distribution of resources, mainly but not exclusively economic resources, and class-based disparities in wealth and income often based on race and racism. Omi and Winant's (2015) explanation of stratification theory and its approaches, which deal with the social distribution of economic resources, is framed from the perspective of the "race versus class" divide (p. 58). The difference is that race and class are different but are often placed together. I believe that Omi and Winant's point of reference is that individuals who receive a similar or equal income or possess equal quantities of wealth are assumed to have similar "life chances" in the hierarchy of classes.

Postcolonial theory largely emerged in the second half of the twentieth century, as countries and peoples once ruled as colonies (such as India, once a British colony, and Algeria, once a French colony) struggled to gain political independence (Routledge, 2016). Similar to critical race theorists, postcolonial theorists contend that oppression and racism are reproduced by social structures and cultural meanings that are much larger than any one individual and outlast any one historical period. Therefore, I can easily apply CRT to my own upbringing when I reflect on growing up in a predominantly White community. I recall that there were very few role models of color who possessed status and wealth, but those who did were well-educated and owned their own homes. Having 
been displaced to a public housing project as a result of family circumstances over which I had no control during my childhood, I learned that such life choices as education and home ownership were life chances that I wanted, and I received the message to many Black youth of my era that college was the only way out. I believe it still is.

Finally, Omi and Winant (2015) stated that, "Race is not only a matter of politics, economics, or culture, but all of these levels of lived experiences simultaneously" ( $\mathrm{p}$. 162). This statement provides me with a greater sense of clarity in my understanding and appreciation for CRT, because lived experiences involve storytelling and storytelling is a direct line into an individual's lived experiences. According to Gloria Ladson-Billings, storytelling is a part of CRT, and the lived experiences of Black people in each of the aforementioned "levels" of race underscores an important point within the CRT paradigm, and that is the idea that race still matters. Race still matters because Americans all over the country continue to experience racism of varying degrees at all levels of politics, economics, and culture. 


\section{Chapter 3: Methodology}

\section{Methodological Framework}

The current research study used a phenomenological methodology to capture individual experiences within a phenomenon as descriptions of their "universal essence" (Creswell, 2013, p. 76). Such a description can happen through the gathering of qualitative methods such as interviews, discussions, and participant observations. Phenomenological approaches are based on a foundational paradigm of personal knowledge and subjectivity, with an emphasis on the importance of human experience, personal perspective, and interpretation as they relate to the commonalities among all participants. Moreover, a phenomenological study can describe the meaning for several individuals of their lived experiences of a phenomenon (Creswell, 2013).

As a research methodology, phenomenology is meant to interpret experiences through the lens of the participant wherein meaning is inferred through the participant's perspective. The researcher must begin the study with an open mind and rid themselves, as far as that is possible, of preconceived notions, relying heavily on dialogue rather than mere observation. Lived experiences occur in a person's life-world before he or she has reflected on or named the experience, though there is always already an interpretative element prior to reflection (van Manen, 1990). In this study, the phenomena are the lived experiences of Black teachers in the classroom and the lack of diversification among their racial group as educators. Throughout the remaining portion of this study, I will use a fictitious name to specify the research site and the word "Teacher" followed by a pronounced number that identifies each participant in the study. 


\section{Location of the Study}

This study required access to two different school districts and three different schools in a medium-sized New England city. The term "urban emergent," as conceptualized by Howard and Milner, means that they are located in a city that is smaller than "major cities" but still faces the same adversities as urban intensive schools but to a lesser degree (Milner, 2012, p. 560). All ten participants came from schools located in urban emergent communities.

Of the ten participants in the study, eight were teachers from the DNA Science Academy. The DNA Science Academy is a Kindergarten through grade twelve, accredited, public charter school committed to improving mathematics, engineering, and science studies for urban youth. The DNA Science Academy has a mission to prepare America's next scientists, engineers, and leaders by providing a rigorous academic program aligned with state requirements. The faculty and staff provide hands-on learning experiences with a strong academic emphasis on science, technology, engineering, and mathematics (STEM). This instruction is augmented by an innovative In-Field Learning Experience program that enables students to observe STEM principles, based on endeavors in the real world.

\section{Sample}

Due to the limited numbers of teachers in the area who specifically identify as Black or African American, it was necessary to substitute two other teachers from the surrounding areas, outside of DNA Science Academy. Therefore, the two other teacher participants were from a middle school and a high school, one in the same district and the other from a district in close proximity. 
There are dependent variables of sample size, and qualitative inquiry is rife with ambiguities. According to Patton (2002), "there are no rules for sample size in qualitative inquiry. Sample size depends on what you want to know, the purpose of the inquiry, what is at stake, what will be useful, what will have credibility, and what can be done with available time and resources" (p. 242-243). One recommendation for phenomenological research is to select a sample size that will allow for the identification of consistent patterns. For this reason, a purposive sample size of ten was selected. In an effort to achieve saturation and limit redundancy, assessing ten Black teachers allowed for the ability to develop a stronger and closer rapport with each participant and their respective experiences. Of the ten participants who participated in this study, six were current classroom teachers, two were building administrators, one was the Dean of Students, and one was a guidance counselor. The participant who was a guidance counselor has never served in the role of a classroom teacher. The participants ranged in age from 38 to 62 years old, and they varied in years of experience in the field of education from 6 years to 38 years. There were seven male and three female participants; demographics are noted in Table 1. 
Table 1

Participant Demographics

\begin{tabular}{lll}
\hline Participants & Current position & Years of service \\
\hline Teacher1 (male) & $\begin{array}{l}\text { high school classroom } \\
\text { teacher }\end{array}$ & 38 \\
Teacher2 (female) & assistant administrator & 30 \\
Teacher3 (female) & elementary classroom teacher & 17 \\
Teacher4 (male) & middle school classroom teacher & 20 \\
Teacher5 (male) & elementary dean of students & 16 \\
Teacher6 (male) & high school classroom teacher & 20 \\
Teacher7 (male) & high school classroom teacher & 18 \\
Teacher8 (female) & high school classroom teacher & 30 \\
Teacher9 (male) & middle school guidance & 6 \\
Teacher10 (male) & counselor & 20 \\
\hline
\end{tabular}

\section{Data Collection}

The two instruments used for collecting data in this study were unstructured interviews and reflexive ethnography/autoethnography. The rationale for using the two instruments was to intimately capture the lived experience of the participants and their feelings and thoughts as to the lack of diversity in their respective schools. Reflexive ethnography/autoethnography allowed me, the researcher for this study, to use my lived experiences in partnering with my colleagues and participants in the sharing of common experiences.

The process of data collection began with the composition of twelve open-ended questions (Appendix A) under four categories: personal education experience, professional experience as a classroom teacher career path, and teacher diversity and 
teacher recruitment and retention. Patton (2002) claims that, "Open-ended questions and probes yield in-depth responses about people's experiences, perceptions, opinions, feelings, and knowledge" (p. 4). Each participant received two documents via email and a hard copy in person prior to scheduling the interview. These documents were a request for study participation announcement (Appendix B) and a consent document (Appendix C). All ten interviews took place in a classroom or office setting, and all participants received a copy of the twelve questions through email 24 hours in advance of their scheduled interview date and time. The interviews were audio-recorded with a cell phone and transcribed through the app Temi to be printed and analyzed. The interviews ranged in time from fifteen minutes to one hour and four minutes.

\section{Semi-structured Interviews}

In the field of qualitative research, interviewing is one of the most widely used methods in investigating a phenomenon. While social researchers commonly use interviewing, the specific interview formats employed often vary. Interviews conducted by phenomenologists, whose main strategy is participant observation, are most often unstructured and similar to a natural conversation. Even in unstructured interviews, however, phenomenologists have already considered the topics that they want to explore and the questions they wish to pose. Thus, such an unstructured interview affords the researcher the ability to direct the conversation with the research in mind and with little structure imposed on the interaction with the participant. In most instances, unstructured interviews occur between individuals who have established an ongoing relationship, one that precedes the interview and will continue after. In such a case, points of discussion 
during the interview usually reference both a shared history of a relationship with an awareness of a continued association.

For the current phenomenological study, semi-structured interviewing offered the flexibility and special accommodations for time and space due to teacher's schedules. This process differs from unstructured interviews. In a semi-structured interview, the researcher has a prepared list of interview questions, which may be as structured or informal as a list of memorized topics. In contrast to the structured interviews, semistructured interviews allow the researcher the freedom to change the wording and the order of the questions, pending the flow and feel of the interview. Participants are also encouraged to expand or digress on a given response or even to go off topic and introduce concerns of their own. Most importantly, in the semi-structured interview, the participants' responses are open-ended, in their own words, and not restricted to the preconceived notions of the researcher.

Research based primarily on semi-structured interviewing has become an important form of qualitative inquiry across the social sciences. The relationship between the researcher and participants extends beyond the immediate parameters of the interview. Semi-structured interviews require attention to the interview's context and the relationship between participants beyond what is said. For these reasons, research based on this form of interviewing is sometimes referred to as ethnographic interviewing and is usually conducted by the researcher with just one participant at a time, though they are often supplemented by focus group discussions between the researcher and participants. 


\section{Reflexive Ethnography and Autoethnography}

This phenomenological study used the method of reflexive ethnography, a method within the emerging qualitative research method of autoethnography. According to Wall (2006), "autoethnography allows the researcher to write using a highly personalized style, drawing on their experience to extend understanding about a societal phenomenon" ( $p$. 1). Wall (2006) further asserts that, "the intent of autoethnography is to acknowledge the inextricable link between the personal and the cultural and to make room for nontraditional forms of inquiry and expression" (p. 1). As this study is a phenomenology of the lived experiences of Black teachers, and since I am a Black teacher, autoethnography afforded me the opportunity to share my experiences within the scope of this distinctly American, cultural phenomenon. According to Sparkes (2000) autoethnographies "are highly personalized accounts that draw upon the experience of the author/researcher for the purpose of extending sociological understanding” (p. 21). Pelias (2003) adds that an autoethnography, "lets you use yourself to get to the culture" (p. 372). My background and unique experiences enable my personal struggles, inferences, and conclusions as a Black teacher to reflect the dynamics of the cultural phenomenon being studied.

Wall (2006) refers to reflexivity as a concept, "in which the researcher pauses for a moment to think about how his or her presence, standpoint, or characteristics might have influenced the outcome of the research process" (p. 3). Phenomenological research seeks to discover lived experience in the context of a unique relationship between researcher and participant. The shared history of a similar encounter that both the 
researcher and the participant experienced at different points in their lives can be profound.

Wall (2006) references the work of Clandinin and Connelly (1994) with their suggestion that the freedom of a researcher to speak as a player in a research project and to mingle his or her experience with the experience of those studied is precisely what is needed to move inquiry and knowledge further along. If a researcher's voice is omitted from a text, the writing is reduced to a mere summary and interpretation of the works of others, with nothing new added (p. 3).

The use of phenomenology, semi-structured interviews, reflexive ethnography, and autoethnography are the best approaches for this study, as the lived experiences of Black teachers are a shared, cultural phenomenon in the United States. Because of my home court advantage, so to speak, of being a veteran Black teacher among the selected participants, I was able to interpret my experiences reflexively and connect them with the culture and experiences of the participants to create a narrative that tells a strong and pertinent story about a persistent cultural phenomenon. Because the interviews were semi-structured, I had the autonomy and flexibility to divert from my prepared questions to gain additional knowledge from each participant throughout our conversations, as we shared similar lived experiences.

\section{Data Analysis}

Following the completion of the ten interviews, the process for data analysis began with the thorough reading of each transcribed interview and the taking of notes on the constructs or key words that came up often as well as quotes that highlighted important concepts or ideas. To begin the process of the initial coding, I used van 
Manen's analytical method, and its three aspects of data analysis were utilized. First, a holistic approach provided an overview of the data; second, the selective approach began in an effort to identify patterns; and third, the detailed approach led to the development of themes (Polit \& Beck, 2008). To continue the process of coding and theme development, a qualitative research software called NVivo12 was purchased to assist with data analysis. NVivo12 enabled the researcher to electronically import data, arrange and sort information, and examine contexts within and between the data.

I incorporated member-checking as a form of validation for my understanding of the participant's narratives. According to Birt, Cavers, Scott, Campbell, and Walter (2016), "Providing opportunities to delete data calls into question the very nature of research data: Are research data 'owned' by the researcher of does it always 'belong' to the participant?" (p. 1805). As a fellow colleague, who shares the similarities of our lived experiences, I wanted to ensure the accuracy of the participant's stories, whether or not they were deleted or retained for adding to their narratives. While reading each interview transcription, I began to extrapolate statements that captured the participants lived experiences as related to the research question.

Lastly, I elicited each sentence to discover and develop essential themes and patterns. Utilizing the holistic, selective, and detailed aspects of van Manen's method ensured thorough analysis of the data. The next step, the writing up of the findings, is also important in van Manen's approach. According to van Manen (2007), "Not unlike the poet, the phenomenologist directs the gaze toward the region where meaning originates, wells up, percolates through the porous membrane of past sedimentations - 
and then infuses us, permeates us, infects us, touches us, stirs us, exercises formative affect" (p. 11). 


\section{Chapter 4: Findings}

In this chapter, I present excerpts from my interviews of the participants' lived experiences of being Black in predominantly White public schools. According to Creswell (2013) a, "descriptive passage that discusses the essence of the experience of individuals incorporating 'what' they have experienced and 'how' they experienced it" (p. 79). The presentation of the findings here is categorized by the four interview categories used for the study: 1) personal educational experience, 2) professional experience as a classroom teacher, 3) career path, and 4) teacher diversity and teacher recruitment and retention.

\section{Personal Educational Experience}

One of the most common themes among the ten participants was in regard to integrated schools. All the participants attended and graduated from elementary, junior high/middle, and high schools that were integrated, with exceptionally low minority enrollments. With the exception of the middle school and freshman year of high school spent in Virginia by Teacher5, the K-2 early elementary experience of Teacher6, and the K-12 experience of Teacher10, all participants were educated in the K-12 public school system of the same state in which they were employed at the time of the study. Most spoke positively about their experiences as students. Teacher1 shared fond memories from the 1960s of his third grade, female teacher: "I used to sit in a chair and just rock back and forth and talk a lot, and, instead of making a big deal out of it, and [turning it into] a discipline thing, she used to call me 'the senator.'

Teacher1 was the longest serving participant in the study, with 38 years of service. He further mentioned that, "A White woman telling a Black child '...you're 
going to be a senator one day' was big in those days." This participant explained further that he did not know exactly what that meant at the time; "As I got older and especially recently as my career begins to sunset, I've been thinking a lot about that woman and the fact that she didn't make a big deal out of it."

Teacher1 later understood what his teacher meant: "She said one day he was going to be something because he talks, but he's smart, but he's always talking... It's spectacular because there weren't a whole lot of Black senators at that time, and it seemed like she was looking toward the future."

Teacher6 spoke very simply and candidly of his personal educational experience and of the high expectations placed on him at home. These later translated into high expectations for his own children and for his students:

I wasn't anti school, I wasn't pro school. I guess my sister being like a super nerd in school, school was kind of forced down my throat, you know, but I wasn't allowed 'B's.' I guess that set me up for college later on. My mom didn't accept 'C's' and said that the only ' $C$ ' that I could have on my report card was the one in my name!

Teacher3 spoke of some difficult memories of her personal educational experience:

It was in this state. I kind of felt a little out of place. There were mostly White students in the schools...then my mom moved out of the projects, then she moved into another apartment complex, but it was like a nicer place and I was bussed to another school where mostly all the students were White and it was like maybe just the kids that rode the bus were Black...It was kind of awkward because there 
were only one or two of us in the classroom, and the teachers mostly favored the White students.

Teacher3 further expressed:

When I got up in high school, it was a little different...Again I was bussed to a school that was predominantly White. I remember one specific time, and I won't forget this, all the Black students, you know, the guidance counselor told us we should take business classes. She wouldn't even help us get ready for college as far as getting in; you know, she wouldn't even speak to us about it. She would say, you should really go and take a business class seat. She really made us feel like...college wasn't for us.

For Teacher3, her desire to pursue her education at all costs is what sustained her through a tumultuous adolescent experience with an adult educator.

Teacher5 also spoke of hurtful and lasting experiences during his time in the state's middle and high schools. During his high school years, Teacher5 was able to turn a negative experience around and in so doing helped lead a school-wide movement to create a more positive experience for himself and others. With regard to his middle school experience, Teacher5 said:

All my teachers were White, and it wasn't as favorable and that was during the time...there was a lot of racism going on. They just had to let us out of school early because the kids would come to the schools with sticks and bats and chains, too, and this was at J_Middle School in the city and it was pretty hellacious. It was one of the worst times in my life as a child growing up in an educational setting where people really just did not like us because of the color of our skin. 
Teacher5 continued:

...and a lot of teachers were Italians and had an allegiance to the folk in a historically Italian part of town, which was one of the predominantly racist areas. They weren't that favorable with students of color, either. My high school years were a little better at that time. My father was in the military at the time we moved to a smaller town in the state and the teachers were more receptive of students of color. I think that's when I became a little bit more conscientious about "where were the people who look like me and why weren't they in the educational setting?" A lot of teachers were afraid of us because of the color of our skin. And when we went into the cafeteria to eat, and I'm talking about the kids of color here out of a school of 2,500 there were probably 20 kids of color in this whole school...so when we into the cafeteria to eat, they would actually get up from the table and move and go to another section of the table. I was a big mouth...I would ask, "What, what is it about us?" And some of the kids said that their parents told them that we were like...they called us the ' $n$ ' word...we stunk, we steal, and were very violent. I challenged them at that time and I said, well, watch us for a little while and if we act like what you have been taught then I understand that, but if not, then you need to find yourself in embracing us rather than pushing us away...and then I found myself talking to the teachers because I was very outspoken and asked them why, "Why is it that you have us sit in the back and not in the front or in the middle with some of the other kids?" And again, you know, they were just like, well, we were told to watch you...so I tried to start breaking the ground and saying, well no, we were going to be treated as an 
equal... I became one of the most popular kids in the school and it changed the atmosphere of the school...Then they started embracing us more rather than pushing us away...That became a positive outcome of that experience.

No other participant expressed such an experience, and for Teacher5 to even consider a career in education after such an experience, I consider a most monumental feat. Such an experience of a young person in school might leave a very heavily negative impression, but Teacher5 was able to turn this around and use it as opportunity for reconciliation, which eventually had a positive influence.

My personal educational experience was similar to that of my participants; I also attended integrated schools from Kindergarten through Grade 12. In my youth, academic achievement was encouraged at school and at home, but I did not take it seriously or make it a priority until my high school years. The public schools of Newport were integrated, but the city itself was segregated by socioeconomic status. The Newport of my youth is an example of de facto segregation because it was clear that certain people just did not live in certain parts of the city. The majority of White kids and families lived in the Fifth Ward or in downtown areas, while the majority of the Black and other minority kids and families lived in one of six low income or subsidized housing projects. My family moved into a house in a suburban part of the city close to downtown when I was four years old and remained there until I completed the fourth grade. I remember vividly that we were the first Black family to live on our street in 1979 and the only one since that time.

During my school years there was not one single teacher who treated me differently because of my color. I do remember, however, that many kids were treated 
with a degree of scorn if it was clear that they did not have a desire to excel academically, especially when they possessed the ability to do so. As I mentioned, during fourth grade, my parents separated, and my mother moved my two older brothers and me to one of the less desirable housing projects. We lived there until I graduated from college and became a public school teacher. In fact, on the first day of school of my first year as a teacher I still lived in the projects, and on my way to school I passed some of the kids who ended up in my classes that day. That was a horrible feeling. I was very proud that I had earned a college degree but was angry that I still lived in the projects. I had just graduated from college and still did not have enough money to live outside of lowincome housing. I remained hopeful because I knew change was coming. Education had already made a difference for me and I knew that education would continue to make a difference in my life.

\section{Professional Experience as a Classroom Teacher}

The most common theme to come out of the professional experiences of the participants was the collective desire to provide all students with a high-quality educational experience and the importance of education as a means of providing equity and opportunity. The majority of participants worked with a large number of students of color, and their desire was to be role models for them.

Most participants expressed that the reasons they became a teacher or entered the field of education was due to a positive experience with an educator when they themselves were students. Additionally, the participants noted that they wanted to give back to the community in which they grew up. They expressed having the responsibility to uphold high expectations as Black professional educators. When asked what led to 
their becoming a teacher, Teacher2 immediately responded: "My high school guidance counselor. I swore I was going into cosmetology and she told me, no you're not, you're going to college, and so I went."

Teacher2 further expressed:

...She was the one who became the reason that I became a teacher, because when she said, 'you're going to college,' I said 'What would I do in college?'; She's the one who pointed out my personality and she said I would be great with kids, and I said okay and ended up at Wheelock College. I received a scholarship and financial aid, so everything, the whole package came together.

When posed the same question about becoming a teacher, Teacher3 stated:

I became a teacher because I noticed that there wasn't a lot of us around and I think that I'm a minority in this. Mostly all the schools in our city have many minority students and they need someone to look up to. They need someone to act as a role model for them. So that's what inspired me to become a teacher...I wanted to be a role model for the students, and I think I am a role model because a lot of the students that are not even in my class, they would come up to me and talk to me and try to get to know me because of my color... I guess they feel comfortable talking to me.

Teacher5 very boldly and proudly described his experience as a Black teacher when he declared:

I'm proud of who I am, and I want the kids that God blessed us to be around to understand that they too can be proud of who they are, but also be even more proud if they can pour what they have into somebody else and make them a 
positive person in society. That's my mantra: I'm going to give you what I have to the best of my ability so that you can become somebody that you want to be. I was greatly encouraged by this mantra from Teacher5 and feel strongly that such conviction and passion in the field of education could only come through in this study.

Like Teacher5, I, too, can very boldly and proudly describe my influence as a Black teacher in sharing my experiences with two boys that I taught in Grade 7. Tony and Carl were two remarkably different students who made a major difference in my life as an educator, and years later they both made it clear that I had made a major difference in each of their lives. I did not teach Tony and Carl during the same school year, but both lived in a low-income single-parent home and without a consistent and positive male image.

I worked diligently with each of them in and out of school, toiling long hours on homework and various school assignments and projects. After finishing Grade 7 both fell victim to their environments and became consumed by violence and crime. Tony and Carl both ended up in jail at different times and for different reasons. During their incarceration they each wrote to me and expressed what I meant to them. Each of them told me that they actually wanted me to be their father, and they thanked me for what I tried to do for them when they were seventh graders and for trying to prevent the unfortunate lifestyle that they chose years later.

The letters I received from Tony and Carl became an expression of the tangible confirmation that I had accomplished something meaningful and what I have always wanted to do as a teacher: make a difference. All I have ever wanted to do for all of the students I have ever worked with is to make a positive difference in their lives and to help 
them to recognize that they, too, have the ability to influence the lives of others in a positive way. Tony and Carl have both been released and are now making better choices and moving in a more positive direction. These two boys never wrote to any other teacher during their incarceration. My lived experience with Tony and Carl is strongly supported by the research of Quiocho and Rios (2000) in their assertion that Black teachers are valuable role models for all students, especially students of color.

Teacher8 is a 30-year veteran of high school mathematics and stated:

My desire was always to teach in an urban school. I want to teach with a diverse student body and I've always been blessed to be able to do so. My experience as a Black teacher has been positive because I'm working with children of color. My classroom is my domain...this is home to me. So as a teacher in the classroom I've been blessed, and I've enjoyed it and my experience has been positive. As my time with Teacher8 progressed it was revealed why her preference has been to work with students of color:

When I did my student teaching at [name of high school], at the time is was predominantly White...there were no Black teachers. There were about five students of color and I was not welcomed in the teacher's lounge. I was ignored for the first week I was there. I just started eating with the kids, you know...thought I was weird and eventually the children of color just started setting up my name and they made me feel welcomed.

This was clearly a career-altering experience for Teacher8 and working with a majority of students of color has created for her a sense of comfort in her career. The lived experience of Teacher8 is supported by the research of Villegas and Irvine (2010) in their 
assertion that Black teachers are often cultural brokers for students of color in that they have the ability to bring an understanding of students' cultural background and experiences. The experience of Teacher8 is further supported by research of Ashely Griffin (2017) in her explanation that Black teachers develop an initial trust and rapport with Black students that help build relationships that promote learning; as a result, students feel safe in their classrooms, thus creating a conducive learning environment.

Teacher9 was the youngest participant in the study, with six years of experience in education as a middle school guidance counselor. He entered the field of education following an interesting experience he had while working in the juvenile justice system: I was working for juvenile drug court as part of family court. I was a case manager there and I started to realize that they know I love working with children. I was getting them in the court system, and it was at that point...I wanted to be a little bit more proactive in preventing them from getting to that level of involvement in the juvenile system. So I figured what better way than in the school system? So I decided to go back to school to be an educator. I chose guidance because I wanted to have more access to students than just the students in my classroom. Being on staff at this school, which is the neighborhood school I went to, I want to be a presence and have more of an impact, and that is my way of giving back to the community, making that my career, my profession. I didn't have that many Black educators growing up and the ones I did have, I still remember their first and last names.

Teacher10, a seasoned school administrator, entered the field of education as a calling: 
I'd say it was more of a calling than anything else because I was going in a different direction, then I felt called into education. Didn't understand what I was getting into. I [originally] felt called to become a doctor...[As a doctor] you have an opportunity to impact some lives, the lives of your patients and helping them to live. Whereas as an educator you have the opportunity to impact even more lives on a different level, helping them to live because you're educating their minds, and so I see becoming a teacher...as having the opportunity to impact far more lives than any doctor can and prepare those lives to impact other lives. That's education.

Teacher10 explained that when he became a principal, he was only 28 years old and was one of the youngest administrators in the state. During this time, he had two obstacles to overcome, age and color. He explained that his assistant principal was an older Black man who had resigned from a previous position when he found a note in his school mailbox, which read, "niggers don't lead!" Teacher10 stated that the reason for the resignation of his older colleague was due to the fact that, when the note was brought to the attention of the superintendent, no investigation took place. Teacher10 shared that, "as a principal, as a leader in this state and in this city as a Black man, I have always had to keep it about the data and about students."

A common theme all participants had agreement with, in regard to their professional experiences, was their positive interactions with students and their positive perceptions by students. Teacher5 and Teacher6 both expressed excitement when talking about their interactions with students and their abilities to have moments of fun with them. Teacher6 stated: 
I think one of the interesting things is being able to talk about topics that are touchy with students. I think that's the greatest thing about being an African American teacher. We can talk about gangs in a way that they're not going to relate to the science teacher. We can talk about the hood and understand each other.

The lived experiences of Teacher5 and Teacher6 (both of whom teach in the same school) are supported by the research of Ashley Griffin (2017) in her assertion that in the end, the most important aspect is "the understanding and acknowledgement that students (all students and especially students of color) benefit from learning in a school building staffed with diverse adults" (p. 2). These lived experiences are further supported by the research of the Albert Shanker Institute (2015) in its statement "all students benefit from being educated by teachers from a variety of different backgrounds, races, and ethnic groups, as this experience better prepares them to succeed in an increasingly diverse society" (p. 1).

Teacher9 was the only participant of the ten who said that his color and having grown up in the same neighborhood made dealing with parents easier:

When I walk in the office, a parent sees me and says, 'I want to meet with this guy' because my skin color makes it easier for me; I'm a Black male, that's who I want to be known as, a Black male what can really relate to you and I'm from the neighborhood.

Similar to Teacher10, teaching was also a calling for me, and I received the clarion during my junior year of high school. My U.S. history teacher for college prep(atory) in 1991-1992 was Mr. Kevin Burns, and he had a unique style of teaching 
that attracted me into considering teaching as a possible career path. During my junior year at Rogers High School, I was a member of the local branch NAACP Youth Council, and at sixteen years of age I was charged with the responsibility of serving as the master of ceremonies for the local Martin Luther King, Jr., Day youth program. I told Mr. Burns about this event and invited him to attend. I will never forget standing up to open the program and seeing Mr. Burns seated in a folding chair in the back of the auditorium. $\mathrm{He}$ was such a special man and an outstanding teacher of history and social studies, and I wanted very much to follow in his footsteps. While it should not matter, I feel that it is important to mention that Mr. Burns was White. Up to that point in my education I had never had a White teacher who had taken a particularly special interest in me or in my educational experiences. For me, at age sixteen, this was a very new and exciting experience.

I will always remember years later when I began my teaching career and on the first day of school of my first year as an educator, both Mr. and Mrs. Burns (who was my English teacher in my senior year of high school) sent me a beautiful arrangement of flowers with a card attached, welcoming me to the field of teaching. In December of 2009, Mr. Burns passed away, and after attending his funeral I wrote a long letter to Mrs. Burns expressing my sympathy. In the letter I expressed the deep inspiration and lasting impression Mr. Burns had left on me. As a couple they had no children, so, when Mrs. Burns wrote back, she expressed the pride that she and her husband had and saw me as their son. I was very moved by her words. Later Mrs. Burns invited me to her home and offered books and other mementos belonging to him. 
Some of the most enjoyable and rewarding moments of my professional experience as a Black teacher have been the many positive relationships that I have built with students. Being the only Black teacher in the building for so long, I have had a unique ability to connect with students, both White and Black, because of being their first Black teacher. Being the only Black teacher in my school building caused me to feel an even greater sense of responsibility to uphold a strong, disciplined, determined, and nononsense "Joe Clark" image. Joe Clark is a well-known Black teacher turned principal, who lead a miraculous school improvement plan of an inner-city high school in New Jersey with his no-nonsense manner of discipline. Research shows that a Black teacher's presence can transform a student's life due to the shared lived experiences that the educator brings to the classroom (Goings, Brandehoff, \& Bianco, 2018; Griffin \& Tackie, 2016). I take my role as a classroom teacher very seriously, as members of my immediate family were unable to secure an education due to unfortunate circumstances. Historically, there were many people within my racial heritage (slaves, maids, cooks, mammies, Pullman porters, etc.) who were forced out of educational opportunities due to Jim Crow laws in the south.

I have always placed a high value on presenting an image of pride and dignity in the way that I dress and present myself as a teacher. In preparing students to attend local functions, such as banquets and luncheons, I modeled how to use a linen napkin and how to select the appropriate eating utensil and drinking glass while seated at a finely dressed table. I prepared many children, Black and White, for such functions and secured the funds and transportation for their attendance over the course of my career. I taught them the significance of image and the importance of wearing a jacket and tie (and shoes, not 
sneakers) or a skirt or dress to certain places and events. I taught them how to shake hands like ladies and gentlemen and how to greet mayors, city council members, and other politicians and community members. I am proud of these experiences and of the fact that the local branch of the NAACP always had a special table reserved for 'Mr. Browner and his students.' The lived experience of going beyond my classroom to provide these experiences for students is strongly supported by the research of Ashley Griffin (2017) in her assertion that Black teachers often feel an obligation to go beyond teaching solely academics and to educate the entire child, including character-building and everyday life skills.

While I have had many heights of joy and contentment as a classroom teacher, unfortunately, the most difficult experiences in my career have been related to my skin color. While many Black students often look to me as a surrogate parent, my White colleagues often look to me as a disciplinarian because of my presence as a Black man. I do not understand the full context for this perception by White colleagues, but I do know for certain that having been raised by a father who is a veteran of the U.S. Navy, and who was a Baptist deacon and Sunday school teacher, I have followed in his footsteps as a strong disciplinarian. I discipline students in a manner similar to the way I was raised, for which I am quite proud and a complement to my parents.

I have experienced microaggressions from administrators and colleagues who have felt justified in using the word nigger in my presence while referencing their disdain for the word when used as a term of endearment among Black students. I have experienced any mail or correspondence related to Black history or old issues of Ebony and Jet magazines being constantly placed in my school mailbox, attached to the 
unspoken yet enduring message, “Give those to Mike Browner, he'll know what to do with them." The experience of White colleagues rushing into my classroom to relay the news of the deaths of Mrs. Rosa Parks and Mrs. Coretta Scott King. As if I am the resident of knowing ALL Black people's experiences, for which they share no responsibility.

These experiences almost never involve children but are perpetuated by adults. For example, the experience of an irate White father whom I thought intended to come to school to discuss the academic standing of his daughter but did not. Instead, he insisted on launching an attack on me that was purely grounded in his own issues with race. In another instance, when I entered the classroom for a meeting and before I was even seated, the parent exclaimed, "Clearly this is a Black classroom!" I explained that while my classroom walls are proudly adorned with images of great Americans who inspire me, many of whom happen to be Black, I politely acknowledged, "Please recognize the images of Abraham Lincoln, FDR, JFK, and the artwork of Norman Rockwell." Another moment, which illustrates the need for strong imagery related to its historical significance and the overwhelming admiration that many children have for its main character, is Norman Rockwell's 1964 painting, The Problem We All Live With. I have always felt that no social studies classroom in this country should be without a print of this painting, which depicts the young and courageous Ruby Bridges being escorted into school by four, White, U.S. Marshals.

I remember another experience during a parent/teacher meeting in my second year of teaching when a White, male parent came to discuss the academic performance and behavior of his son, John. John was a peculiar child with a silly demeanor; he would 
often say and do silly things that brought negative attention to himself. Many of his peers found it difficult to take John seriously and to get along with him. During this meeting with me and several other school personnel, John's father expressed an incident of bullying that John had related at home, and apparently in doing so John had used the word "nigger." John's father was not very happy with the school and blamed us for his son hearing, and learning, the word at school. The father looked directly at me and said, "My son learned the word 'nigger' here." As usual, I was the only person of color in the room and the fact that the parent felt compelled to freely use the word in my presence was a disheartening experience that I will never forget.

The tension in the room was thick, and the eyes of my colleagues dropped to the floor. There seemed to be shame and embarrassment from my White colleagues. I was insulted by this parent and disappointed in my colleagues. I felt nervous while trying to determine the best action in response to this situation. I do not remember what I said, if anything, but I do remember not knowing what to do because I was the only Black person in the room. I felt lonely and isolated. I was 23 years old at the time of this incident. Congressman John Lewis of Georgia was just 23 and the youngest representative of the SNCC (Student Nonviolent Coordinating Committee) when he spoke at the March on Washington in 1963 and, prior to that only 21 when he was nearly killed during a 1961 freedom ride in Alabama. Remembering both events of this historical figure, I wonder what he would have done in my situation? Being called a nigger is not the worst experience that a Black man can have, but it was one of the worst experiences of my life up until that point. I also remember feeling that this parent knew what he was doing and 
had decided to do it before the meeting began. I felt the parent knew what he said and the reaction it would capture; however, he said it anyway.

In the years since, I have learned to believe if such great Americans as Dr. Martin Luther King, Jr., Mr. Medgar Evers, Mrs. Rosa Parks, and U. S. Representative John Lewis, and Mrs. Shirley Chisholm, can soldier up, then I can as well. This experience took place twenty years ago and I have gained much knowledge from my professional experiences since then. My only advice to others who may experience similar situations is to consistently exude self-respect and dignity: two character qualities that come from within and cannot be taken away. In any such instance it is always appropriate to remain calm and stay focused on what is best for the student. For years, this experience left a painful scar, but it has since faded and replaced with memories of parents who have shown the utmost appreciation and respect.

\section{Career Path}

Under the heading of career path, the participants and I approached the discussion of experiences and successes as a Black teacher. The responses from the participants were personal and specific rather than the generalized experiences I had anticipated. Teacher1 expressed that one of his career successes as a Black teacher was offering the first African American history course at the middle school level in his district. He had finished a degree program in African American studies in 1999 and said: "I started the class of like twelve and then over the intervening years I've had three classes of 27 apiece." Teacher1 went on to say that, "I still have a full classroom... so that would probably be the lasting...my greatest professional success." Teacher1 concluded that his greatest success will be bringing a 40 -year career to a close in two years when he turns 
64 , “...that's 40 years of classroom [service]; that's hero's work and I'm ready to sunset, shut the lights off and I'm done."

Two of my participants, Teacher1 and Teacher3, both referenced their recognition as Teacher of the Year to be one of their greatest successes; however, both still considered their work with students to be the proudest of their professional accomplishments. Teacher 3 further stated:

My classroom was chosen to test the NCTM (National Council of Teachers of Mathematics) standards and they gave me the Senate materials and I had to teach that material and my kids did so well that they asked me to go out to other schools. So I went to [name of school] and other schools and watched teachers so I could critique how the math teachers were teaching. But at the end of the year when the kids took the MAT (Metropolitan Achievement Test), their scores were off the charts in math. I'll never forget that because I had the most fun with those kids. I didn't want to teach fifth grade anymore because they wore me out. That was the first time in my career, and I was only like five years in at that point, but it was the first time where I saw success and I saw it make a difference for kids and those are the kids that are still trying to contact me.

According to Teacher5: "Success has been having positive role models in my life which has enabled me to become a positive role model for students and the fact that as a result of my impact, they've always come back. Even if they have moved away, they stay in contact or they make referrals: my cousin is coming over there, so I want you to make sure you look out for my cousin, too...to me that's success!" 
Teacher8 expressed something that I believe many teachers across the field of education express at some point in their career:

I've gotten a few awards.... the latest one I got this year was the student choice award; that was my favorite because they chose me...but it's just knowing the students and seeing them years later. I just saw someone from my first year in 1988, my first class and she's a teacher now and to see her and just say, wow, you know, I'm old.

Teacher7, one of the two teachers of high school mathematics among the participants, expressed his successes as a classroom teacher:

I'm proud that we've sent students off to do interesting work in computer science to places like URI and Boston University; the CSTA (Computer Science Teachers Association) of Rhode Island is providing leadership training and I'm glad to be a part of that and it's something I feel really proud of. I was also asked to teach a university level class as a member of CSTA.

Teacher7 further expressed a feeling of success in his involvement in the Launch Code Program out of St. Louis where:

We had students who were able to secure jobs with starting salaries of $\$ 70,000$ and $\$ 80,000$ six weeks after this program, which is actually pretty cool that those kinds of jobs are available, and a lot of kids were able to further their careers through our work and that's something to be very proud of.

Teacher7 referenced his most significant career success as a Black teacher as having been able to "bring together different ideas and being able to bring together a lot of different 
strands and then make students feel comfortable with those strands; students see me as an ally, and they trust me when I talk about these connections and relationships."

As I listened to and conversed with Teacher6 and Teacher7, I noticed that we had much in common because we were all Black male teachers in a similar age bracket, and we all related to a reference that Teacher7 described more than once as "The Cosby Show thing." We were all heavily influenced by The Cosby Show and its message of education and academic achievement. We discussed the positive image that both lead characters in the show, Cliff and Clair Huxtable, held for Black youth during the eight seasons of the show on NBC, and the fact that it was not a show about a Black family but rather a show about an American family. This show and its legacy left a lasting impact on each of us. Unfortunately, today our students do not have many positive images of educated Black parents and families to look to in the media. We all agreed that we, as Black teachers, have a responsibility to youth to emulate the educated image that show portrayed, and to help kids to recognize their full potential to become well-educated and professionally employed.

Teacher9 expressed that his greatest success as a Black teacher has been "the opportunity to work in this school, a school I attended as a child. I started off as a focus counselor, which was a job that no one wanted. That was my way to get a foot in the door." Teacher9 further stated:

I find success in coming to work and smiling; it doesn't feel like work because I'm enjoying myself. People sometimes question if I'm really working because I'm smiling working with great young people and pretty much trying to change the narrative of the negative perspectives of this area. 
The school where Teacher9 serves is in a part of the city with many low-income and high-crime neighborhoods, and local schools often receive a poor reputation for those reasons.

I did my student teaching at the same school in 1998 during the spring semester. I had the greatest experience of my life and as a result was very well-prepared to begin my career as a teacher of middle school social studies. My cooperating teacher was an outstanding and dedicated teacher for many years at the time, and she was well loved by former and current students alike. She exhibited great skill in pedagogy and an unending enthusiasm, and, in doing so, she taught me to be prepared and to always take teaching seriously. Following the completion of my student teaching assignment and after graduating from Rhode Island College in May of 1998, my cooperating teacher made it possible for me to deliver the keynote address at the school's eighth grade promotion ceremony.

Teacher10 began the administrative journey of his career at a young age and stated:

I would say success has been each of the [administrative] positions that I've held as the youngest principal in the state. I believe somebody saw something in me to say that, okay, we're going to take a chance on this guy. Becoming a principal at age 28 and the fact that someone would trust me to lead one of the lowest performing schools in the state was a success. That school made adequate yearly progress for the first time in history after my third year as principal. I later became a supervisor of science curriculum for the district and then became the executive director of this place. These are all successes that I'm proud of. 
Listening to Teacher 10 express pride in his successes as a Black educator not only made me proud of him but also proud of the opportunity to have met a new colleague and been granted the privilege of having him be a part of my study. Teacher10 further expressed the development of personal leadership that has sustained him in his successes and in his ability to continually grow as a leader:

There are a lot of factors that you have to take into consideration in every decision you make. The factor that has helped lead to my success has been a focus on personal leadership development. It's beyond education; it's beyond what you do in college to get your degree because everybody has the same degrees. How is it that one person can lead more effectively than others? An individual must make a conscious decision to focus on their personal leadership to become a better leader. I've remained committed to personal development as a leader because it's leadership principles that affect the organization. As the leader grows, the organization grows, if the leader doesn't grow, the organization can't grow. I was named the Teacher of the Year in my district for the 2007-2008 school year at age 32 and ten years into my career. I was proud of this accomplishment and the opportunity to have competed at the state level for this prestigious award and was named among the top three teachers in the state. My greatest success has been my ability to build a strong rapport and lasting impression with my students. The students I taught in my first year are now 33 years old and I have had so many of them return to my current school to say hello or send me handwritten notes and emails about their personal or professional lives with warm words of thanks. 
I recently had a former female student remind me that she was in my social studies class on the morning of September 11, 2001. She spoke of feeling safe in my classroom when I read the letter from the superintendent's office. The student felt everything was going to be all right because of my calm demeanor as I shared the news with the class. I am thankful for such reminders of my service and relationships with students.

Under the previous heading of Career Path, the responses from the participants were very personal and specific. The majority of Black teachers (eight out of ten) included in the study were from the DNA Science Academy. These teachers did not express the challenge of isolation because of having each other; however, Teacher1, for nearly his entire 40 years as a classroom teacher, had been isolated and did not share racial identifications with his colleagues. This speaks to my experience at the school where I currently teach. I have been a teacher there for twenty years, and for at least sixteen of those years there was not another colleague who shared the same racial background. This feeling of isolation and the absence of camaraderie with colleagues of the same racial background have been challenging to my career as a Black teacher. Teacher2 spoke of her most challenging experiences as both a teacher and an administrator:

Interactions with colleagues have not been the greatest. That's the biggest challenge, working with colleagues and trying to be collaborative and people not wanting to be collaborative but rather competitive, which is not my style. A lack of collaborative effort, even from other Black teachers, remains a challenge. 
Teacher3 took a moment to consider her challenges and then clearly expressed a racial microaggression:

I did have a challenging situation about four years ago. I had a kindergarten student and I don't think her mother wanted me as the teacher. The student was a White girl and her mother thought she was a princess. The girl was nice, but the mother was not, and she complained about me constantly. The mother went to the principal complaining about me, and the principal took her side. One day the mother was out in the parking lot talking about my class. I wanted to meet with her and the principal to let them both know that they should observe the child's behavior themselves. The problem was bullying, which was a big problem at the time. Every day the child went home and told her mother she was being bullied, even though she was not; in fact, she was doing most of the bullying. The real problem was that when the children would play tag one boy was playing tag with her and he tagged her in the face instead of on her shoulders. She went home and told her mother that a boy slapped her face. The mother came into school very upset. It was a bad situation and the mother ended up taking her daughter out of my class. It ended well because the problem was resolved, but it resulted in me losing a student.

The experience shared by Teacher 3 could be classified as a racial microaggression because the parent seemingly began the relationship with the teacher with a cold demeanor and had no real desire for her daughter to be in the classroom of a Black teacher. The bullying incident seemed to have been a coincidental occurrence that enabled justification for the parent to pull her child out of the class altogether 
For Teacher4, the greatest challenge has been interactions with parents: "At times, some parents take my honesty, and it can be brutal, as unprofessional. One of the parents was lecturing me on how to speak to children. Here I was a 20-year veteran teacher." Teacher4 is not a novice teacher and his experiences have trained him to speak with great conviction about his knowledge of pedagogy and other aspects of his job and sometimes, in so doing, his delivery may be perceived as "brutal" by some. The context of the problem in this example came from Teacher4's experiences in regard to a parent that felt this teacher was not approachable to her son, and who felt that he couldn't talk to the teacher. Teacher4 told her, "Your son doesn't even try to talk to me because he knows what the rules are. He knows what he's supposed to be doing." Teacher4 continued: "You don't need to talk to me about how to speak to anybody because I got this. You know your son. I have to deal with 20 at a time; your son is one, and I have 20 other people's kids." Teacher4 explained that she tried to explain to him again, "I had to let her go, and then she told the principal."

Teacher6 and Teacher7 both shared challenges in their ability to relate to their students. Teacher6 expressed: "You get the homeboys that don't see you as hard, so they want to test you." Teacher6 shared an experience at a Saturday SAT preparation session when a male student who was known as "hard" exhibited some challenging behavior in the testing center and the teacher had to say to him quietly:

You're going to have to bounce and get the hell up out of here or we're going to have a problem. And he kind of looked at me like, you can't talk like that. It was just weird for him to realize like, damn, he just spoke to me like someone on the street. 
Since Teacher6 is familiar with the streets, it was easy for him to move into this role; however, it was challenging because a teacher does not want to confront a student in the manner of the streets.

Teacher7 expressed some previous challenges relative to classroom management and the fact that he is not at all from an urban background. Growing up in a predominantly White community, Teacher7 stated: “I've worked hard to make calls home and provide clear instructions and make sure students know what's important. Maybe my background or not being someone who is from the streets impacts my view of the world, but things have improved during my time here." Teacher7 seemed to feel that over time he has found his niche at DNA Science Academy and takes much pride in his work with the students there.

Teacher8 focused very closely and very thoughtfully on herself as a reflective practitioner about her relationships with her students relative to her responses about her greatest challenges:

I think for my own personal challenge with my students is getting them to see who they are, getting them to see the worth of value, letting them know that what you have here is not what you're going to face in the real world and trying to build them up as young men and women of character. And that's my challenge because I'm competing with social media and home lives that aren't that great and moms and dads who are just not there. We're telling them negative things about themselves. My challenge is to just feed into their souls while getting them to see themselves in a positive way and building them up. 
Teacher8 further expressed another challenge in her relationships with her students:

For me it is listening to what the students say about me and being really honest. What I love about children of color, in particular, is that they're brutally honest if they feel they are not being treated fairly. They say, 'You let him come in late, you didn't give him detention, but you gave me detention, why is that?' And I have to question myself and I'm like, you know, you're right. And listening to what they say is important to me because this is how I grow. I value being able to teach a student with a 504 or an IEP because I didn't take any special education classes. I study the IEP and I implement the accommodations to the whole class; if one student needs notes, the whole class gets notes. If one student needs me to break it down, then I do it for the whole class.

Admittedly, it was difficult for me to distinguish this example as a success or challenge because Teacher8 turned the often-challenging deed of meeting special education accommodations into a success for herself and for her students. Teacher8 also shared the challenge of dealing with parents:

One of my biggest challenges, though, is parents. I had a terrible experience when a parent cussed me out, came up to the school, complained about me for calling their house, and so I'm always very hesitant about contacting parents. I know it was a long time ago, but it's still the last thing for me; if I'm calling your parents then you had to do something really bad. But that's something that I'm still working out after 30 years; I'll do everything I can before I have to call the parents. 
Former U.S. Secretary of Education, Dr. John B. King, Jr., was one of the first to reference the invisible tax for Black male teachers: the unspoken challenge of being looked upon as the sole disciplinarian or the one who can save all Black children simply because of his presence as a Black man. Teacher9 said:

My biggest challenge is [they] want me to be the savior and that constantly strict male presence, which I think is good and necessary at times, but there's a time and place for it but it's not all the time. They think it's all the time. Why do I have to have that militant mentality all the time?

The expression of this challenge from Teacher9 caused me to think of the same invisible tax that I have experienced many times, the challenge of White teachers and other colleagues thinking that I, too, could save every Black child. I have had guidance counselors specifically place the most challenging Black students in my class and it has not always been easy. It is true that I am a heavy-handed disciplinarian and yet skilled at getting difficult students to feel comfortable and behave themselves. However, when the principal comes into a meeting and says, "Okay Mike, work your magic with [so and so]!" it is extremely difficult to be consistently thought of as a professional magician who can just turn around the worst-behaved child with little difficulty. I cannot save every Black student, nor should I be expected to. This challenging lived experience is supported by the research of Griffin and Tackie (2016) in their statement "without the acknowledgement of the pedagogical and subject matter expertise essential to their profession, they felt they lacked opportunities for advancement and were undervalued and unappreciated" (p. 1). The lived experiences that I have expressed here have certainly led to feelings of being undervalued and unappreciated. 
Teacher10 has a mantra for personal growth and personal leadership development, and even in his challenges he has managed to find a way to grow. Teacher10 stated:

I would say the challenges have actually made me better. The challenges of color were painful, but they made me better. You can become bitter or you can become better because of your critics. I have no room for error because there are folks who are just looking, waiting to exploit that weakness. Everyone is paid to become a problem-solver, and the minute you start creating problems, then there is a problem. For me, when I look at critics and opposition and folks who are critical of decisions and choices that I make, I think, okay, is there anything valid or of substance to that criticism? If the answer is no, disregard it, and if the answer is yes, consider if it's better for the organization. My greatest challenge was when I was a principal at the lowest performing school in the state and the superintendent at the time specifically placed me there; he said 'I need you there. I need a person of your temperament there.' That was probably one of the most challenging experiences, but it made me better. The first year was a mess. I was a first-year principal and I couldn't anticipate the veteran individuals that wanted to see me fail, but I got up. I had a mentor the second year and that mentor helped me.

For Teacher10, his successes came with the realization of the need for a mentor, which eventually helped lead to his ultimate goal: "The school made adequate yearly progress because historically it was a low performing school."

Teacher5 opened up very personally about his greatest challenge: 
Probably one of the biggest challenges was the death of my wife. My wife passed away of cancer 17 years ago and we had three children, and it was extremely impactful in my life. I didn't think I'd make it mentally. My youngest son was five and just started school when my wife passed. That was one of the things that impacted my career the most because I felt that I would probably have to walk away from education completely and just be a 'Mr. Mom,' and I was concerned about my kids. How is my wife's death really going to affect them? How are they going to turn out? And fortunately, thank God, they turned out okay. As far as greatest challenges are concerned, I myself made a strong connection with the experience of Teacher5 after having lost so many family members during a two year period of my teaching career. It is amazing how personal loss can affect the performance of a classroom teacher. In February of 2017 I lost my mother and during the 2017-2018 school year there were four deaths that I experienced. The first was a former student who finished the seventh grade and committed suicide. I was the student's and the mother's teacher, and I delivered the eulogy at the funeral. My late mother's sister died in October, and my paternal grandfather died in November. I delivered eulogies at both those funerals, as well. Six months later in May of 2018, my grandfather's wife (my second paternal grandmother) died, and I was again asked to deliver her eulogy.

Writing and delivering five eulogies in a period of fifteen months began to take a physical and emotional toll, and I sought help from my medical doctor. He suggested that I take the last three weeks of June off from work to regroup myself. When I told the kids at school that I would be taking a leave, through their tears and disappointment, they understood and wished me well. I believe that my boys and girls reacted this way in part 
because, as the only Black teacher in the building, I stand out for them and bring to them an experience like no other. These challenges may not be directly related to classroom teaching, but they have been the great for my career. The loss of my mother has been much worse for me than a parent using the word nigger in a meeting. The fact that my students at school have been there to offer comfort through many of these experiences has been remarkable.

\section{Teacher Diversity and Teacher Recruitment and Retention}

In response to my interview questions, all participants expressed the ways in which the greatest benefit of teacher diversity is the ability to be a role model for all students (ASI, 2015). There was an overall theme of acknowledgement of the need for greater teacher diversity. There was also a heaviness over these questions that represented a feeling of hopelessness that growth in the number of Black teachers will likely remain stagnant in the years to come. There were few suggestions or recommendations for how to recruit and maintain Black teachers. The majority of the participants have toiled in education for so long themselves that they can almost understand and accept the reasons why so many young Black professionals are not entering the teaching field. Participants highlighted such reasons as low starting salary, which often makes repaying student loans very difficult. The existence of other more attractive fields that pay well from the beginning without the annual steps/scales and the necessity to earn another degree to make more money rather than career advancement were also noted by participants as relevant to departure. Of the ten participants, four had less than twenty years of experience in the field and the average age was over forty years old. None of the participants seemed burned out and all are still working hard at their 
respective schools. However, there was an understated reality that if any of these ten participants left their schools or retired, they might not be replaced by another Black teacher. Early in my career there were three other Black teachers at my school and when all three retired, or moved to a different job or district, none were replaced by Black teachers.

Teacher1, Teacher8, and Teacher9 agreed on the perspective that the best time to begin to recruit prospective Black teachers is the present, when students are enrolled in the same schools, which we all now serve. As the longest-serving teacher among the participants for this study, Teacher1 is no stranger to the lack of teacher diversity but offered a unique way to identify prospective Black teachers very early:

We need to go to the middle schools and start to identify kids and find some way to work with them and potentially work with them in high school to identify them. Because here's what's happening: we've hired three or maybe four social studies teachers in the last few years. We would have 300 or 400 applications and then no one. There's a couple of reasons: one of them is we keep saying we want the best and brightest, but then they cut our pay and we become the lowest paid in the state, who's going to come here? Second of all, if you're a young minority you've got to get a job that pays because, if you don't, six months later you've got student loans knocking on the door. You have to get a salary that pays them. And we keep saying we want paid lip service to the best and brightest in education. I think the other thing is that they're just not going into the field because there are other well-paying avenues. 
Teacher1 spoke of how many young Black professionals are simply seeking greater financial security earlier in their careers and the reality that the starting salary for a novice teacher is too low.

Teacher9 also supported the perspective of identifying prospective Black teachers as early as middle school:

My way of thinking is we need to start from middle school; we could get all of the educators of color together and have some type of forum about careers in teaching while the kids are in middle school. That way, by the time students are in high school, they have already begun to consider teaching as a career path. There needs to be something with the state colleges where students can have their education paid for if they enter teaching or commit five years of service. Our recruiting needs to be within state's school districts with the greatest needs. I think there needs to be more of a male presence, because right now I'm the only male out of like 70 educators in the building.

Teacher1 offered further suggestions about teacher education programs: getting students out and into classrooms much earlier than practicum and student teaching. Teacher1 stated:

I think we need to start identifying kids earlier, nurturing them and staying with them through the university process. And we need to get kids into classrooms earlier; they should be in classrooms their sophomore year and they should spend more time student teaching. Students should be in student teaching for the full school year. I know it's hard because you have to give them a class that they can 
teach for a year, but they need to do it. One semester is not enough. And if you can identify kids earlier then they'll know if this is what they want.

Teacher8 also supported the same idea of starting to identify prospective teachers earlier:

I would probably start in high school; some kids love science and want to do something with math and talk about teaching. They want to make money, but they also see the challenges that we face. We can start in the high school and then the transition [into teaching] becomes easier once they get to college. Teacher 3 expressed the importance of the collegial experience among Black teachers that is an important benefit:

As a Black teacher I think it's very important to have diversity in the schools. There is one other Black teacher in the elementary section here besides myself, and it's great having her and somebody to lean on and talk to because you go through things that you don't want to share with your White colleagues because it's not the same and you don't know how they're going to take it. I can go to her with anything and feel comfortable. If I didn't have her, I would probably feel isolated, with nobody to talk to; she and I, we get together outside of school and have become good friends. As far as recruitment, I think Black teachers are out there trying to get a job. I know a few myself that are trying, and they just cannot get one permanently. I think they should look out and try to recruit them somehow; they should put minorities in the school because of the population of the students and because it's only going to help. 
Teacher4 also expressed the benefit of collegiality among the Black teachers at DNA Science Academy: "Black teachers here get along with each other for the most part; yes, some more than others, but here the Black teachers feel comfortable with one another, get along with each other, and kind of go to bat for each other if it's necessary." I personally have only experienced the benefit of having Black colleagues for a few years of my career, but I do agree that it is indeed valuable.

Teacher4 offered a perspective on the benefits of teacher diversity that I could easily identify with, one that is inclusive of all teachers: "I think anybody can create a relationship with a student. A student will look at you differently on your color; however, they still don't look at you as the same Black person that they would see outside in the street." Teacher4 further expressed the significance and the strength in creating relationships:

Because I speak Spanish but am not Hispanic, I can check some of the kids with certain words that they hear at home, which fosters the relationship. I think if you create a decent relationship with the child, what you look like doesn't matter because it's the relationship that makes the difference for them.

Teacher4 also expressed the same sentiment regarding relationships with Black parents and families: "Parents sometimes come in and feel a little intimidated; they don't want a whole bunch of White people standing there telling them what's wrong with their child. Sometimes I have been called into meetings simply because I've already created a relationship with parents.”

Throughout my own career it has been my experience that teachers across races and cultures can create dynamic and lasting relationships with students (and with parents 
and families), but there is often a very special relationship and bond that is created between Black teachers and Black students, which is among the greatest benefits of teacher diversity. Teacher5 supported this mindset about the relationship between Black teacher and Black student as a benefit:

Because you're able to identify with the race and you're able to identify with the struggles that the kids are going through and, when you don't have that, there's a huge part of the puzzle that's missing and we can't really get the richness out of the kids that we could get otherwise.

Regarding teacher recruitment and retention, both Teacher4 and Teacher5 expressed their concern about teacher diversity as it currently exists in the state. Teacher4 noted: "Other places are doing better than us in this regard. However, the people that get educated in the state have a tendency to leave. They don't want to stay here." Teacher4 did not offer any reasons why educated Black people are leaving the state, but Teacher5 added: "If the teachers of color are leaving the district or the area because of the pay, then we need to offer more money and let them see the need [rather than] making it appear as if it's better on the other side. There's a great need and we can do better."

Teacher7 expressed that, because of the diverse student population, the school has not really worked that hard to develop an equally diverse teaching staff:

It's just what we do here at the school. I mean we've just brought in diverse teachers, but I don't think we've brought diversity in because it's not been something we've had to work too hard at. We've been pretty diverse here and 
we've been a long-lasting faculty; I've been here 17 years and other teachers have been here longer.

Teacher7 seemed proud of teacher longevity at DNA Science Academy especially through some tumultuous changes in the school's administration. However, he kept his primary focus on the benefits of teacher diversity for students:

The great thing about having a diverse community is that students are less likely to get lost. Another factor is the size of the school; there's always someone around that the students can relate to. The positive aspect is that we've got more sounding boards, more teachers that students can feel comfortable with in all aspects. Teachers here give value to students. Teaching is a very special commitment; teaching is awesome.

Teacher8 also expressed her belief in the importance of teacher diversity but not only as a presence of Black professionals in schools: "I just think it's important that we just have more of us here and out in the community and not always in an urban setting, but in suburbia it is even more important." Teacher8 continued, sharing an experience which supports her belief of the need for more awareness in both urban as well as suburban communities:

I was with my daughter and we were walking through an outdoor mall and some young men yelled out the window and called out 'nigger' to me. I just kind of laughed and kept going. My daughter was shocked. And having gone through it my whole life I just explained that he's an ignorant child so it's not going to faze me, and I had to educate her on that. And her not ever having experienced that because she grew up in a school like DNA Science Academy. The benefit of 
teacher diversity is that these children can see that we are valued, we have something to offer, too.

Teacher10 expressed the perspective that although the district has not been intentional about teacher diversity:

DNA Science Academy as a school is a very unique place, especially in the high school, where we have a very diverse staff, midline elementary division, not so much, but the high school was the first part of this project, the seventh through twelfth division. What we have not done as a district or even as a school is to be intentional about recruiting minority candidates.

Teacher10 clarified that it is not necessary for a school to have an all-Black or minority faculty, but it needs to be diverse because students also have to know how to deal with other people, to learn how to deal with all kinds of people. He illustrated this point by saying:

What I'm saying is people need to be held accountable for student achievement, but they also have to be willing to have the flexibility and the autonomy to get the right players on the team. If you have the right players on the team, I look at it as a principle very similar to coaching a team; everybody in the organization itself must be accountable to the students and to student achievement.

Teacher10 further expressed the benefits of teacher diversity:

Being able to connect. There's a trust factor that's given from parents by being a teacher of color; they are saying I trust you with my kid because of who you are, I trust you to give my kid what I've heard about. And it's a great feeling to be able to. 
Teacher10 also made his entire perspective student-focused:

Why are we here, what is the goal? Student achievement. Let's start there and have a conversation about that, because at the end of the day that's the real reason why we're here. Students need to achieve, they need to progress, they need to move forward, they need to be prepared, and if they're struggling then we need to find out why and then put the plan in place to help.

Teacher10 projected the mantra that teacher diversity is important but more importantly must be grounded in student achievement.

As I have stated previously, for the majority of my career I have been the only Black teacher in my school building and in most of my professional experiences to date. It has not been an easy experience being the only teacher of color for nearly twenty years, and the experience of working with other professionals who share my race and ethnicity as well as my passion for education is an experience that I still long to have. The experiences that have been expressed in this chapter thoroughly answered my research question and have provided much clarity on the rationale for increasing the number of Black teachers and the value which teachers of color, especially Black teachers, contribute to schools and classrooms.

While teacher diversity is a critical issue in all areas of education, it is particularly important in public schools. I believe very strongly that a school district must first and foremost recognize teacher diversity as an issue worthy of attention at the local level. School districts must have school committees in place that are intentional about recognizing the significance of the impact that a diverse teaching force can have on the lives of all students and families. In most communities, school committee members are 
elected officials who must be the first line of individuals who take up this cause and lead superintendents, central office staff, human resource personnel, building principals, and teachers to become a collective force to create an environment in which all students can begin to recognize themselves in the faces of those who instruct them.

This force of stakeholders must begin to accomplish this work through a process of intentional strategic planning wherein teacher diversity is an integral component and stands at the forefront as an important aspect of helping to move a school district forward. If this work continues to go undone, the result will be that young Black and minority children who do not see themselves in their teachers will begin to believe that Black and minority people do not teach. Students of all races and backgrounds need to be exposed to the reality that not every well-educated professional in the field of education is White. The work of diversifying the teacher workforce in this state and beyond must begin with the very people involved in education right now. 


\section{Chapter 5: Discussion}

The foregoing statements of this phenomenological and autoethnographic study spotlight the interpretation of the lived experiences of Black teachers and the challenges experienced therein. The statements are not intended to minimize the differences in the experiences of the study's participants but to provide a descriptive interrelatedness of them as a collective unit of teaching professionals.

\section{Implications for Future Applications of CRT}

This study provides a platform for future applications of Critical Race Theory (CRT) as a lens to explore the lived experience of Black teachers. Through a review of the literature, an emerging trend of framing educational research through a CRT lens was illuminated. Through this spotlight, CRT emerged as a response to critiques of legal studies that failed to acknowledge the impact that laws have continually played in perpetuating inequalities (Crenshaw et al., 1995). This theory has helped researchers to highlight how society has been shaped by racism and the roles that race plays in social contexts and systems. By applying CRT to education, researchers (Brown, 2014; Kohli, 2009, 2014) have employed a theoretical lens that has explored how Black teachers are impacted by race. From the literature review and by analyzing the results of this study, CRT presented an appropriate theoretical lens to further explore the experience of Black teachers.

\section{Limitations}

The nature of qualitative inquiry in phenomenological research requires the composition of questions that enable a direct route to responses that capture lived experiences. The questions that were posed to the participants in this study warranted 
responses in the first person to directly gauge the lived experiences of each participant as far as that was possible. This was achieved in each of the four categories of questions and furthermore in the autoethnographic responses of the author. Additionally, though the participants are listed with gender identification (Table 1, p. 30), the design of the questions did not give differentiation in gender differences. The subject of gender was not addressed and therefore, the responses from the participants were specifically about their lived experiences of being a Black teacher without reference to gender. Had the differentiation of gender and being a Black teacher been combined, the responses could have provided a more in-depth outcome to the lived experiences of the participants. This limitation offers the need for further research.

According to Patton (2002), "there are no rules for sample size in qualitative inquiry. Sample size depends on what you want to know, the purpose of the inquiry, what is at stake, what will be useful, what will have credibility, and what can be done with available time and resources" (p. 242-243). A recommendation for phenomenological researchers is to select a sample size which will allow for the identification of consistent patterns, hence the selection of a purposive sample size of ten for this study. The assessment of ten Black teachers allowed for a stronger and closer rapport with each participant and their respective lived experiences.

As a qualitative study with a small sample size, this study is not generalizable to a broader population. Marshall, Cardon, Poddar, and Fontenot (2013) examined the justifications of eighty-three qualitative research studies; they recommended that, "grounded theory qualitative studies should generally include between 20 to 30 interviews" and, "the maximum [30] [is] where additional interviews fail to produce 
substantial new insight" (p. 20). In the case of this study, had I included a greater number of participants the study could have been challenged by repetitive information from participants that offered no new valid information based on my examination and analysis of the data. With ten total participants, the study provided sufficiency in data and a clear understanding of the phenomenon, but had there been a few more interview participants, the study might have provided greater insight into the problem.

\section{Summary}

The Black teachers in this study all had the opportunity of attending integrated schools but with few Black teachers or other school personnel. Though none of the participants expressed any remorse that most of their teachers were White, it is a factor that made a difference and one they would not like to see repeated for their students. Each participant shared their lived experiences and the influences which led them in the field of teaching. The personal educational experiences and influences of the ten participants were clearly articulated, which allowed for an analysis of the data to create a unique narrative of the phenomenon under study. Each participant expressed an experience or influence that had an impact on the professional that they are today; they each expressed the desire to have that same impact on all students, particularly on students of color. I had many excellent teachers in my personal education experiences, but it was Mrs. Barge who provided with me a strong cultural pride and that alone has had the greatest impact on me both personally and professionally. Because Mrs. Barge was my only teacher of color, her ability to bring to my life a lasting sense of cultural pride was very unique and personal.

\section{Professional Experience as a Classroom Teacher}


The Black teachers in this study are aware of the educational and societal inequalities that exist in the United States. They are also conscious of their identities and how other people use their identities to perceive them as inferior and often challenge or question their judgement, skills, or knowledge of pedagogy. With this consciousness, it is my belief, borne out by this study, that Black teachers tend to enter the field of education with a fierce humanistic commitment to provide a social justice-oriented experience for all students and more intentionally for students of color. As teachers they tend to possess a limitless belief in their students' potential and hold remarkably high expectations in order to facilitate the success of all students.

\section{Career Path}

In order to become better educators for all students, these Black teachers tapped into their lived experiences, especially those related to race and culture, to connect with students and families. Regarding their identities, prior to entering their teaching careers or while in their teaching careers, Black teachers had been in environments where they were the only one or one of a few Black teachers in an educational environment. Being in either situation had left some of these Black teachers feeling isolated and had taken a social-emotional toll. For example, the invisible tax of being the primary disciplinarian in many instances or being thought of the hero or savior for all Black and minority students. can have a draining effect on the endurance of Black teachers and their ability to maintain a steadfast focus on student learning. In some instances, certain social connections with former teachers, guidance counselors, and/or mentors provided an alliance of support that assisted these Black teachers, which demonstrated the teacher's professional abilities to adjust and reflect on their individual teaching practices. 
These Black teachers hoped to be recognized by administrators, colleagues, and families for their skills and knowledge of pedagogy, not only for their race, culture, or ability as a skilled disciplinarian. While in their careers, these Black teachers also felt a sense of fulfillment by linking their lived experiences to those of their students and their families by offering a non-judgmental stance on the experiences or situations of their students and their families. Advocating for students and families, especially those of color, was a serious, meaningful aspect of their commitment to education.

\section{Teacher Diversity and Teacher Recruitment and Retention}

For nearly my entire twenty-year career as a teacher in public education, I have been the only teacher of color in my school building. From my own lived experiences as a Black teacher, and from the lived experiences of the participants in this study, I highly recommend that educational leaders and policymakers first acknowledge the role race plays in society, for children and adults, and its impact on equitable education and/or career opportunities. It needs to be acknowledged that the reality of race still impacts the education of Black children in public schools and the types of jobs available to them based on their educational experiences and attainment. It is imperative to analyze current hiring practices, policies, and systems to identify ways by which to create a more diverse pool of candidates.

For example, if the office of human resources in a given school district has limited knowledge of teacher diversity and its benefits, or if such an office is completely occupied solely by White personnel, then chances are that there will be little effort in seeking a more diverse pool of candidates. That has been my experience throughout my entire career in public education, and, in instances where I have personally discussed with 
school department leaders, the response has frequently been that candidates are not out there, meaning extant. The utilization of such organizations as Nemnet Minority Recruitment (a national consulting firm that assists with the recruitment and retention of teachers of color), as well as the establishment of connections with organizations that promote a diverse pool like HBCUs (Historically Black Colleges and Universities), could help to move toward greater teacher diversification.

The deficit in the number of Black teachers and other teachers of color is a nationwide epidemic. Creating statewide campaigns to address and promote teachers of color in the classroom, including providing alternative and highly credible avenues to certification, could be a task of local and state educational leaders working collaboratively with local and state policymakers. The recommendation from some of the participants in this study is to identify prospective teacher candidates as early as middle school and high school and provide incentives for Black undergraduate students and other students of color to pursue careers in teaching. A key recommendation for those already working in the trenches and on the front lines in classrooms is to identify Black teachers and other teachers of color to be involved in the hiring process and decision-making to diversify the workforce.

Finally, in keeping with the purpose of this study, educational leaders and policymakers need to establish a district-based or regional meeting group or mentorship programs that support, discuss, process, and share the stories and lived experiences of Black teachers and other teachers of color. Since 2016, there has been an organization in Rhode Island named the EduLeaders of Color Rhode Island. EduLeaders of Color Rhode Island provides a space where teachers of color and leaders in the education field can 
meet and share thoughts, ideas, and experiences about their careers, and the educational inequities that exist throughout the state and the nation. This organization is currently developing a system of leaders and educators of color to build its network and elevate the voices in its coalition. The work and mission of EduLeaders of Color Rhode Island welcomes all and involves educators of all backgrounds but maintains a specific focus on creating a supportive space for groups of people that historically have been underserved, underrepresented, and marginalized.

In all educational settings, it is essential to analyze pedagogy, scrutinize standardized testing, revisit curricula, and assess support systems to ensure that students of color in particular are provided a successful and purposeful educational experience. It is also imperative to provide students of color with mentors (some of whom look like them), foster a close connection with teachers who believe in them, and have students of color explore experiences in teaching at a young age to promote teaching among people of color.

Valuing and listening to Black teachers about their experiences of life and education provides educational leaders and policymakers with direct contact and knowledge from the constituents whom they wish to recruit. Black teachers and their lived experiences play a vital role in providing information to support diversifying the teacher workforce. As the experiences from this and prior research indicate, Black teachers would seem to enter education with powerful and humanistic commitments to education. Researchers have suggested that Black teachers connect with students utilizing cultural synchronicity, have unyieldingly high expectations, and provide a 
caring, safe learning environment for all students, specifically for students of color (Griffin, 2017; Ingersoll \& May 2016; Villegas \& Irvine, 2010; Quiocho \& Rios, 2000). In my career, I have had the distinct pleasure of hearing in person a staunch advocate committed to improving the lives of children in America, the dynamic Marian Wright Edelman. Edelman (1999) advised, "Be a good ancestor. Stand for something bigger than yourself. Add value to the Earth during your sojourn. Give something back" (p. 166). Providing a platform for the Black teachers in this study to communicate their lived experiences was my way of being a good ancestor and giving back to the rich bounty of my community. As the struggle continues to provide equitable education for all children and the campaign persists to diversify the teacher workforce, educational leaders, policymakers, parents and families, politicians, educators, and community members should seek collective ways to give back and, as individuals, stand for something bigger than themselves. Diversifying the teacher workforce is one such effort in improving the lives of children and providing an equitable education for all students.

\section{Recommendations for Further Research}

Additional research on the topic in this study should expand on qualitative methods to deepen the knowledge of the lived experiences of Black teachers and to offer a more holistic and comprehensive assessment of diversity in education. Black teachers were once children in an educational setting that may have offered them a limited view of themselves and their potential as students. Black teachers have a depth of knowledge and a wealth of experiences to offer from both a personal and professional perspective. Hearing about more of the lived experiences of Black teachers would provide valuable information for the recruitment and retention efforts of a diversified teaching faculty. 
In education there are professional role differences for men and women, regardless of race. Further research should look at both race and differentiation of gender in education, to examine the effects of race and gender on pedagogy, behavior, autonomy, and career advancement within the profession. Finally, further research on this topic should consider the application of CRT as a theoretical lens, to further explore the experiences of Black teachers. By examining how Black teachers are impacted by race in the educational system, researchers may be able to shed light on the successes and the challenges of Black teachers through this theoretical lens. 


\section{Appendix A \\ Interview Questions for Teacher Participants}

\section{Personal educational experience:}

1. Describe the elementary and secondary schools you attended.

2. How did you feel about school, teachers, and your own academic achievement?

\section{Professional experience as a classroom teacher:}

1. What lead you to become a teacher?

2. Describe your own experience as a Black teacher.

3. How do you feel you are perceived by students, parents, and colleagues? You may include any perceptions including race/ethnicity, personality, teaching practices, et cetera.

4. Describe your interactions with students, parents, and colleagues.

\section{Career path:}

1. What successes have you experienced as a Black teacher? What factors helped lead to these successes?

2. What challenges have you experienced as a Black teacher? How have these challenges impacted your career?

3. What successes and/or challenges have been the most significant in your career?

\section{Teacher diversity and teacher recruitment and retention:}

1. Share your thoughts on teacher diversity from your experiences as a Black teacher?

2. What are the benefits of teacher diversity from your experiences as a Black teacher? 
3. What suggestions or recommendations do you have for recruiting and retaining Black teachers or other teachers of color in your district or generally within the field of education? 
Appendix B

\section{Request for Study Participation Announcement}

I am Michael Browner, Jr., a doctoral student at the University of Rhode Island and Rhode Island College, Ph.D. program in Education. I am conducting a research project to interview Black teachers to tell their stories concerning whether or not there is a need to recruit Black teachers to diversify American pubic classrooms.

A manila folder and envelope have been disseminated to your mailbox through the assistance of the principal's secretary. The manila folder contains a Request for Study Participation Announcement and a Consent Form. After reading the Request for Study Participation Announcement and Consent Form, please sign the consent form if you agree to voluntarily participate. Once you sign the consent form please place it in the folder and then into the envelope and submit to the principal's secretary by Monday, May 14, 2018. The envelope should be sealed before submitting to the principal's secretary. She will place your information in a portable locked file provided by me and store it in a locked closet. I will pick up the portable locked file by the end of the school day on Monday, May 14, 2018 to review participants' participation. I will contact each participant with the scheduled interviewed day and time proposed on the consent form through your school email address. A reminder email confirmation will be sent to each participant the evening before the interview.

Thank you,

Michael Browner, Jr. 


\section{Appendix C}

\section{Perspective on Teacher Diversity and the Lived Experiences of Black Public School}

\section{Teachers}

You are being asked to be in a research study as a Black teacher to tell your story as to whether or not there is a need to recruit Black teachers to diversify American public school classrooms. Please read this form and ask any questions that you have before choosing whether to be in the study.

Michael Browner, Jr., is a doctoral student at the University of Rhode Island and Rhode Island College, Ph.D. Program in Education, and will be conducting the study. Dr. Stefan Battle, an Assistant Professor at Rhode Island College, is the PI (Principal Investigator) for the study.

\section{Why this Study is Being Done (Purpose)}

We are doing this study to explore the possible need to diversify American public classrooms with Black teachers for the benefit of students to explore racial and cultural differences. By establishing a more diversified representation of Black teachers in the classroom, White educators could use their Black colleagues as "cultural anchors" to help them with their in-class conversations and challenges of racial and cultural differences among all students not only students of color.

\section{What You Will Have to Do (Procedures)}

If you choose to be in the study, we will ask you to:

- First, the doctoral student will contact you to participate in an interview based upon the information you provide in the subheading below of this consent form: Additional Information Needed.

- Second, the doctoral student will interview you in a private designated area at Times 2 Academy that the principal has provided. You will be asked to respond to four subgroups of topics with questions for each: Personal educational experience; Professional experience as a classroom teacher; Career path; and Teacher diversity and teacher recruitment and retention. You will be audio taped. This will take about an hour to an hour and a half.

\section{Risks or Discomforts}

You may find that answering some of interview questions upsetting. I think it would be similar to the kinds of things you talk about with friends, family, and some colleagues. You can skip any question proposed to you. If you want to talk to someone about your feelings or about problems that you're having, arrangements have been made to discuss concerns with Dr. Rudolph Moseley, Executive Director of Times 2 Academy. If there is a fee for service, you will pay it. I will not pay fees of service. 


\section{Benefits of Being in the Study}

Being in this study will not benefit you directly.

\section{Deciding Whether to Be in the Study}

Being in the study is your choice to make. Nobody can force you to be in the study. You can choose not to be in the study, and nobody will hold it against you. You can change your mind and quit the study at any time, and you do not have to give a reason. If you decide to quit later, nobody will hold it against you.

\section{How Your Information will be Protected}

Because this is a research study, results will be summarized across all participants and shared in a dissertation that I publish and presentations that I give. Your name will not be used in any reports. We will take several steps to protect the information you give us so that you cannot be identified. Instead of using your name, your information will be given a fictitious coded name. The information will be kept in a locked office file and seen only by myself and other researchers who work with me. The only time I would have to share information from the study is if it is subpoenaed by a court, or if you are suspected of harming yourself or others, then I would have to report it to the appropriate authorities. Also, if there are problems with the study, the records may be viewed by the Rhode Island College Institutional Review Board responsible for protecting the rights and safety of people who participate in research. The information will be kept for a minimum of three years after the study is over, after which it will be destroyed.

\section{Who to Contact}

You can ask any questions you have now. If you have any questions later, you can contact Michael Browner, Jr. at: mbrownerjr@gmail.com or@401-835-1302 and/or Dr. Stefan Battle at: sbattle@ric.edu or 401-456-8753.

If you think you were treated badly in this study, have complaints, or would like to talk to someone other than the researcher about your rights or safety as a research participant, please contact Cindy Paula at IRB@,ric.edu, or by phone at 401-456-9720.

You will be given a copy of this form to keep.

Additional Information Needed:

Here is my school email address:

I am available to be interviewed on the follow days: (please circle as many): Mon, Tues, Wed, Thurs, Fri

Here are times that I am available to be interviewed on the days that I have identified above: 


\section{Statement of Consent}

I have read and understand the information above. I am choosing to be in the study "Perspectives on teacher diversity and the lived experiences of Black public school teachers". I can change my mind and quit at any time, and I don't have to give a reason. I have been given answers to the questions I asked, or I will contact the researcher with any questions that come up later. I am at least 18 years of age.

I___agree __ do not agree to be audio taped for this study.

Print Name of Participant:

Signature of Participant: Date:

Name of Researcher Obtaining Consent: 


\section{Bibliography}

Adam, T. E., Jones, S. H., \& Ellis, C. (2015). Autoethnography. New York: Oxford University Press.

Ahmad, F. Z., \& Boser, U. (2014). America's leaky pipeline for teachers of color: Getting more teachers of color into the classroom. Center for American Progress.

Albert Shanker Institute. (2015). The state of teacher diversity in American education.

Birt, L., Scott, S., Cavers, D., Campbell, C., \& Walter, F. (2016). Member checking: A tool to enhance trustworthiness or merely a nod to validation? Sage, 26, (18021811).

Bogdan, R., \& Biklen, S. K. (2007). Qualitative research for education: An introduction to theories and methods, (5 $5^{\text {th }}$ ed.). London: Pearson.

Boser, U. (2011). Teacher diversity matters: A state by state analysis of teachers of color. Center for American Progress.

Brown v. Board of Education, 347 U.S. 483 (1954).

Brown, K. D. (2014). Teaching in color: a critical race theory in education analysis of the literature on preservice teachers of color and teacher education in the US. Race Ethnicity and Education, 17(3), 326-345.

Clandinin, D. J., \& Connelly, F. M. (1994). Personal experience methods. In N. K. Denzin \& Y. S. Lincoln (Eds.), Handbook of qualitative research (pp. 413-427). Thousand Oaks, CA: Sage.

Crenshaw, K., Gotanda, N., \& Peller, G. (1995). Critical race theory: The key writings that formed the movement. The New Press. 
Crenshaw, K. (1988). Race, reform, and retrenchment: Transformation and legitimation in anti-discrimination law. Harvard Law Review, 101 (7), 1331-1387.

Creswell, J. W. (2014). Research design: Qualitative, quantitative and mixed methods approaches. Thousand Oaks, CA: Sage Publications, Inc.

Creswell, J. W. (2013). Qualitative inquiry \& research design: Choosing among five approaches, third edition. California, London, New Delhi; Sage Publications.

Delgado, R., \& Stefancic, J. (2012). Critical race theory. New York: New York University Press.

DeRuy, E. (2014). Why the country's lack of teacher diversity is a problem. Fusion.

Edelman, M. W. (1999). Lanterns: A memoir of mentors. Beacon Press.

Evans, B. R., \& Leonard, J. (2013). Recruiting and retaining black teachers to work in urban schools. Sage, 3, 1-12.

Flanagan, G. (2010, August 20). Education secretary says U.S. may need more minority teachers: $C N N$. Retrieved from http://www.cnn.com/2010/POLITICS/08/28/duncan.minority.teachers/

Ford, D. Y. (2010). Reversing underachievement among gifted Black students: Theory, research and practice (2nd ed.). Waco, TX: Prufrock Press.

Freire, P. (1993). Pedagogy of the oppressed. New York, NY: Bloomsbury.

Gay, G. (2000). Culturally responsive teaching. New York, NY: Teachers College Press.

Goings, R. B., Brandehoff, R. \& Bianco, M. (2018). To diversify the teacher workforce, start early. Educational Leadership / May 2018, 50-55. ASCD.

Gordon, R. (1990). New developments in legal theory. In D. Kairys (Ed.), The politics of law: A progressive critique (pp. 413-425). New York, NY: Pantheon Books. 
Griffin, A. (2017). The Black Teacher Effect. Washington, DC: The Education Trust. Griffin, A., \& Tackie, H. (2016). Through our eyes: Perspectives and reflections from black teachers. Washington, DC: The Education Trust.

Grissom, J. A., \& Redding, C. (2016). Discretion and disproportionality: Explaining the underrepresentation of high-achieving students of color in gifted programs. AERA Open, 2(1), 1-25.

Harris, C. (1993). Whiteness as property. Harvard Law Review, 106(8), 1707-1791.

Huber, L. P., \& Solorzano, D. G. (2014). Racial microaggressions as a tool for critical race research. Race, Ethnicity and Education, 1-24.

Ingersoll, R. \& May, H. (2016). Minority teacher recruitment, employment and retention: 1987 to 2013. Learning Policy Institute, 1-8.

Keats, E. J. (1962). The snowy day New York, NY: Viking.

Kena, G., Musu-Gillette, L., Robinson, J., Wang, X., Rathbun, A., Zhang, J., Wilkinson-

Flicker, S., Barmer, A., \& Dunlop Velez, E., (2015). The condition of education 2015 (NCES 2015-144). Washington, DC: U.S. Department of Education.

Kohli, R. (2016). Behind school doors: The impact of hostile racial climates on urban teachers of color. Sage, 1-27.

Kohli, R. (2014). Unpacking Internalized Racism: Teachers of Color Striving for Racially Just Classrooms. Race, Ethnicity and Education.

Kohli, R. \& Solorzano, D. (2012). Teachers, please learn our names!: Racial microaggressions and the K-12 classroom. Race, Ethnicity and Education, 1-22.

Kohli, R. (2009). Critical Race Reflections: Valuing the Experiences of Teachers of Color in Teacher Education. Race, Ethnicity and Education, 12(2): 235-251. 
Kozol, J. (2005). The shame of the nation: The restoration of apartheid schooling in America. New York, NY: Random House.

Kozol, J. (1991). Savage inequalities: Children in America's schools. New York, NY: The Trumpet Club.

Ladson-Billings, G. (1998). Just what is critical race theory and what's it doing in a nice field like education. International Journal of Qualitative Studies in Education, $11(1), 7-24$.

Marshall, B., Cardon, P., Poddar, A. \& Fontenot, R. (2013). Does sample size matter in qualitative research? A review of qualitative interviews in is research. Journal of Computer Information Systems, 54(1), 11-22.

Martin, B. (1991). From Negro to Black to African American: The power of names and naming. Political Science Quarterly, 106(1), 83-107.

Milner, H. R. (2012). But what is urban education. Urban Education, 47(3), 556-561.

Moustakas, C. (1994). Phenomenological research methods. Thousand Oaks: Sage Publications.

National Center for Education Statistics [NCES], (2015).

National Education Association. (2004). Assessment of diversity in America's teacher workforce: A call to action. Retrieved from http://www.ate1.org/pubs/uploads/diversityreport.pdf

Omi, M., \& Winant, H. (2015). Racial formation in the United States. New York: Routledge.

Patton, M. (2002). Qualitative evaluation and research methods (3rd ed.). Thousand Oaks, CA: Sage Publications. 
Patton, M. (1999). Enhancing the quality and credibility of qualitative analysis. Health Services Research, 34(5), 1189-1208.

Pelias, R. J. (2003). The academic tourist: An autoethnography. Qualitative Inquiry, $9(3), 369-373$.

Pierce, C. (1988). Stress in the workplace. Black families in crisis: The middle class, edited by A. Coner-Edwards and J. Spurlock, 27-34. New York: Brunner/Mazel.

Pierce, C. (1969). Is bigotry the basis of the medical problem of the ghetto? Medicine in the ghetto, edited by J. Norman, 301-314. New York: Meredith Corporation.

Polit, D. F., \& Beck, C. T. (2008). Nursing research: Generating and assessing evidence for nursing practice. Philadelphia, PA: Lippincott Williams \& Wilkins.

Priest, H. (2002). An approach to the phenomenological analysis of data. Nurse Researcher, 10(2),50-63.

Quiocho, A., \& Rios, F. (2000). The power of their presence: Minority group teachers and schooling. Review of Educational Research, 70(4), 458-528.

Richman, T. (2018). Baltimore schools set up efforts to recruit, retain black teachers. The Washington Post (September 3, 2018).

Routledge (2016). New Connections to Classical and Contemporary Perspectives Social Theory re-wired: Critical Race and Postcolonial Theory.

Rubin, H. J., \& Rubin, I. S. (2012). Qualitative interviewing: The art of hearing data (3rd ed.). Thousand Oaks, CA: Sage Publications.

Smith, T. W. (1992). Changing racial labels: From "Colored" to "Negro" to "Black" to “African American.” Public Opinion Quarterly, 56, 496-514. 
Sparkes, A. C. (2000). Autoethnography and narratives of self: Reflections on criteria in action. Sociology of Sport Journal, 17, 21-43.

Taylor, E., Gillborn, D. \& Ladson-Billings, G. (2016). Foundations of critical race theory in education. New York, NY: Routledge.

U.S. Department of Education, National Center for Education. (2015). Racial/Ethnic enrollment in public schools. Retrieved from http://nces.ed.gov/programs/coe/indicator_cge.asp

U.S. Department of Education, National Center for Education. (2012). Digest of Education Statistics, 2011 (NCES 2012-001), Introduction and Chapter 2; U.S. Department of Education, National Center for Education Statistics, Schools and Staffing Survey, Teacher Data Files, 2007-08. Retrieved from http://nces.ed.gov/fastfacts/display.asp? $\mathrm{id}=28$

U.S. Department of Education, National Center for Education. (2012). Digest of Education Statistics, 2012 Schools and Staffing Survey, Teacher Data Files, Retrieved from http://nces.ed.gov/pubs2012/201245 3.pdf

van Manen, M. (1990). Researching lived experience: Human science for an action sensitive pedagogy. London: Ontario: Althouse Press.

van Manen, M. (2007). Phenomenology of practice. Phenomenology \& Practice, 1(1), 11-30.

Villegas, A., \& Irvine, J. (2010). Diversifying the teacher force: An examination of major arguments. The Urban Review, 42(3), 175-192. 
Villegas, A. M., Strom, K., \& Lucas, T. (2012). Closing the racial ethnic gap between students of color and their teachers: An elusive goal. Equity \& Excellence in Education, 45(2), 282-301.

Wall, S. (2006). An autoethnography on learning about autoethnography. International Journal of Qualitative Methods, 5(2), Article 9. 